\author{
IRA C. LUPU†
}

For almost fifty years, judges, constitutional scholars, and informed citizens have been drawn to the blinkered view that the First Amendment's religion clauses involve the separation of church and state. ${ }^{1}$ Derived primarily from the Supreme Court's centurybridging references to Jefferson's metaphorical wall, ${ }^{2}$ the motifs of distance and dissociation reflected in the idea of separation have been among the enduring images of contemporary constitutional law.

The metaphor, like all such creatures, channeled and therefore limited thought. Even worse, its image was idealized and thoroughly unreal. For both individuals and communities, the metaphor suggested a psychologically and socially impossible discontinuity between the sacred and the secular. Human beings cannot neatly compartmentalize their religious and nonreligious thoughts; communities do not segregate their religious institutions and leaders from others. ${ }^{3}$ Moreover, the metaphor does not account

† Professor of Law, National Law Center, The George Washington University. Thanks to participants in the George Washington Faculty Workshop for their helpful comments and questions, to Theresa Lauerhass, Darin Levine, and Peter Schlossman for their fine research assistance, and to Jerry Barron, Ned Foley, and Bob Tuttle for valuable critiques of an earlier version of this paper.

${ }^{1}$ See U.S. CoNST. amend. I.

2 The language of separation appears in a letter from President Jefferson to the Danbury Baptist Association and refers to the religion clauses as a whole. See Everson v. Board of Educ., 330 U.S. 1, 16 (1947); Reynolds v. United States, 98 U.S. 145, 164 (1878).

${ }^{3}$ These are commonplace propositions in the psychology and sociology of religion. See, e.g., GERHARD LENSR, THE RELIGIOUS FACTOR: A SOCIOLOGICAL STUDY OF RELIGION'S IMPACT ON POLITICS, ECONOMICS, AND FAMILY LIFE 120-31, 158-59 (1961) (discussing correlations between religious affiliation and political party affiliation); GEOFFREY E.W. SCOBIE, PSYCHOLOGY OF RELICION 122-23, 126-27 (1975) (noting the relationships among religion, political attitudes, and society); MAX WEBER, The Relationship of Religion to Politics, Economics, Sexuality, and Art, in THE SOCroloGy OF RELIGION 223, 223-45 (Ephraim Fischoff trans., 4th ed. 1963) (discussing the interplay of religion and politics); Robert F. Drinan, Religion and Politics in the United States in the Next Fifteen Years, in RELIGION AND PoLrTICs 17, 31 (Fred E. Baumann \& Kenneth M. Jensen eds., 1989) (noting that "[t]he ideals of churches have become, to a remarkable degree, the morality of the government"); Ernest L. Fortin, Church Activism in the 1980s: Politics in the Guise of Religion, in RELIGION AND POLrTICS, supra, at 33 (commenting on Christianity's "massive involvement of its leadership in the 
for all of the decisional law ${ }^{4}$ and is unreasonably tilted toward nonestablishment and away from free exercise. The idea of separation of church and state thus presents an image untrue to both life and law. In this respect, it may be headed for a fate similar to that which befell its cousin from the field of race law-the doctrine of separate but equal. ${ }^{5}$

The constitutional era in which separation is the dominant theme appears to be over. Clouded by inevitable tendencies toward oversimplification, however, the debate about religion and the Constitution is once again being framed in overly narrow terms. Rather than strike out bravely toward a new, more refined approach to constitutional questions concerning religion, judges and commentators appear to be in search of a neat replacement for separation.

As a result, the concept of accommodation has been rapidly gaining ground as the central motif of religion clause thought. The idea of accommodation of religion is complex in its details, but simple in its basic premises. According to the accommodationists, the religion clauses have the unitary focus of facilitating the people's religious liberty, and government promotion of such liberty is in the service of constitutional values. The Free Exercise Clause should therefore advance, and the Establishment Clause should recede, in constitutional prominence. ${ }^{6}$

great social and political debates of our time"); John S. Mill, Utility of Religion, in SOCIOLOGY AND RELIGION: A BOOK OF READINGS 96, 96-100 (Norman Birnbaum \& Gertrude Lenzer eds., 1969) (referring to the "temporal usefulness of religion").

${ }^{4}$ Both Board of Education v. Allen, 392 U.S. 236, 248 (1968) and Zorach v. Clauson, 343 U.S. 306, 315 (1952) upheld state-church joint ventures of a sort deeply inconsistent with a separationist view. More recently, in Bowen v. Kendrick, 487 U.S. 589,593 (1988), the Supreme Court rejected a facial challenge to a federal program that provided grants to private organizations, including those with a religious character, for the purposes of responding to the problems of teenage sexuality and pregnancy. Though not widely noticed, Bowen has set the stage for a general repudiation of much of the law of church-state separation in the aid context. For a criticism of accommodation of religion in recent Supreme Court decisions, see Ira C. Lupu, The Trouble With Accommodation, 60 GEO. WASH. L. REV. (forthcoming March 1992).

${ }^{5}$ See Plessy v. Ferguson, 163 U.S. 537 (1896), overruled by Brown v. Board of Educ., 347 U.S. 483 (1954).

${ }^{6}$ In the academy, Professor Michael McConnell is the leading contemporary advocate for the concept of accommodation, and his work is rigorous and thoughtful in its embrace of that notion. The most forthright presentation of his view appears in Michael W. McConnell, Accommodation of Religion, 1985 SUP. CT. REv. 1 [hereinafter McConnell, Accommodation]. Professor McConnell's work has roots in a number of prior writings on the religion clauses. See, e.g., Alan Schwarz, No Imposition 
I would like to say that this movement toward accommodation is an improvement over the prior state of affairs, but I believe it is not. The sense of harmony and tolerance evoked by the image of accommodation is undoubtedly attractive on the surface. Nevertheless, when compared with separation, the new image is equally limiting, equally untrue to large portions of the relevant case law, and unreasonably tilted in the opposite direction-that is, toward free exercise and away from nonestablishment.

In what follows, I stake out one version of the anti-accommodationist position. ${ }^{7}$ I do not intend, however, to embrace the

of Religion: The Establishment Clause Value, 77 YALE L.J. 692, 727-37 (1968) (arguing that the Establishment Clause only prohibits aid that has as its motive the imposition of a particular religion). Professor McConnell's version is unique, however, because of his aggressive promotion of the general notion that government should be both sensitive to and supportive of religion. For additional discussion by Professor McConnell of his pro-accommodation message, see Michael W. McConnell, Neutrality Under the Religion Clauses, 81 Nw. U. L. REV. 146, 148-49 (1986) [hereinafter McConnell, Neutrality] (arguing that government neutrality may in some cases be insufficient to meet the needs of religious practitioners); Michael W. McConnell, The Origins and Historical Understanding of Free Exercise of Religion, 103 HARV. L. REV. 1410, 1511-17 (1990) [hereinafter McConnell, Origins] (arguing that an interpretation of the Free Exercise Clause that mandates religious exemptions was within the contemplation of the framers of the Constitution); Michael W. McConnell \& Richard A. Posner, An Economic Approach to Issues of Religious Freedom, 56 U. CHI. L. REV. 1, 4-14 (1989) (proposing an economic definition of neutrality to determine when government action impermissibly impinges on religious choice).

No one on the Supreme Court is an accommodationist in the same vein as Professor McConnell-that is, no Supreme Court Justice is a champion of both an invigorated Free Exercise Clause and a minimalist Establishment Clause. Justice Blackmun may be the only sitting Justice who is in the former camp, and Justices Scalia, Kennedy, and White, and Chief Justice Rehnquist are firmly in the latter camp.

${ }^{7}$ A number of the seeds of the anti-accommodation argument put forward in this piece have been sown in my earlier work. See Ira C. Lupu, Free Exercise Exemptions and Religious Institutions: The Case of Employment Discrimination, 67 B.U. L. REv. 391, 399-431 (1987) [hereinafter Lupu, Religious Institutions] (criticizing free exercise exemptions for institutions); Ira C. Lupu, Home Education, Religious Liberty, and the Separation of Powers, 67 B.U. L. REv. 971, 979-90 (1987) [hereinafter Lupu, Home Education] (defending state policies designed to divide power over children by forbidding home education, even if motivated by religious choice); Ira C. Lupu, Keeping the Faith: Religion, Equality and Speech in the U.S. Constitution, 18 CoNN. L. REv. 739, 742-55, 761-69 (1986) [hereinafter Lupu, Keeping the Faith] (arguing that the religion clauses intersect with concerns for constitutional equality); Ira C. Lupu, Where Rights Begin: The Problem of Burdens on the Free Exercise of Religion, 102 HARV. L. REv. 933, 966-90 (1989) [hereinafter. Lupu, Where Rights Begin] (defending the concept of judicially created free exercise exemptions and seeking ways of making the doctrine more evenhanded); Ira C. Lupu, Risky Business, 101 HARV. L. REV. 1303, 1315-20 (1988) (book review) (criticizing Corporation of the Presiding Bishop of the Church of Jesus Christ of Latter-Day Saints v. Amos, 483 U.S. 327 (1987), and the concept of permissive accommodations). 
Supreme Court's unsound decision in Employment Division, Department of Human Resources v. Smith, ${ }^{8}$ which (paradoxically, it may seem at first to some) has weakened my argument by eliminating what I view as the only appropriate occasion for government accommodation of religion. Indeed, the best I can say for Smith is that it has damaged the case for accommodation more than it has undercut the case against it.

The title of this piece suggests hope as much as criticism. My view is not so much against the idea of accommodation as it is for the idea of balance in our understandings of the religion clauses. Taken together, the clauses are most persuasively construed as mandating a regime of equal religious liberty. Under such a regime, every person may pursue religious freedom to the extent it is fully compatible with the equal pursuit of religious freedom by others. ${ }^{9}$ If accommodation is simply an overstride toward such a balanced view, the concept may yet prove salutary. If, however, accommodation represents a set of ideas driven by zeal for religious liberty and is consequently insensitive to concerns for equal respect in the actual distribution of such liberty, the concept bears within it the seeds of great harm.

This Article proceeds as follows. Part I defines accommodation and highlights recent decisional law on the subject. Part II explores the purposes of the religion clauses, with particular concern for the narrowness of the accommodationist vision of those purposes. Part III focuses on Smith and its special significance for the constitutional law of religious accommodation. Part IV then responds to two arguments frequently advanced by accommodationist forces: one argument concerns religion clause conflict, and the other is about coercion as a limiting principle in Establishment Clause adjudication.

The bulk of the paper resides in Part V, The Case Against Accommodation. Part V(A) presents the normative case, in which I distinguish substantive and formal versions of religious equality

8110 S. Ct. 1595 (1990); see infra part III.

${ }^{9}$ See JOHN RAWLS, A THEORY OF JUSTICE 60, 201-16 (1971) (arguing for equal rights to basic liberty "compatible with a similar liberty for others" and defining freedom of religion as a basic liberty); see also RONALD DWORKIN, TAKING RIGHTS SERIOUSLY 150, 179-83 (1977) (interpreting Rawls' fundamental principle of liberty as a "right to equal concern and respect in the design and administration of the political institutions"); DAVID A.J. RICHARDS, TOLERATION AND THE CONSTITUTION 103-62 (1986) (arguing that equal respect for persons entails the "moral and constitutional primacy of religious toleration"). 
and offer both constitutional and nonconstitutional grounds for preferring the latter. Part $\mathrm{V}(\mathrm{B})$ extends the argument into the institutional case against accommodation, in which I argue for the intrinsic superiority of adjudication over legislation as the instrument for special treatment of religion. Finally, in Part V(C), this Article explores the implications of this institutional proposition for judicial-legislative cooperation in affording distinctive treatment to religion, with particular attention to the significance of Smith.

\section{ACCOMMODATION DEFINED}

Before I can sensibly proceed, a definition of terms is in order. For me, government accommodation of religion has a straightforward, two-part meaning. The phrase refers to actions taken by the state or its agents that 1 ) respond affirmatively to religion-based claims for exceptional treatment, which would not be afforded but for the religious quality of the claims or the religious character of the institution(s) advancing the claims, ${ }^{10}$ and 2) are not required by the Free Exercise Clause or any other provision of the Constitution. ${ }^{11}$

The definitional requirement that accommodation requests be claims for special or exceptional treatment helps to bound the category with which we are concerned. Most importantly, this criterion excludes general programs of government benefits,

${ }^{10}$ This portion of the definition (though not the second portion) is shared by Justice Scalia. See Texas Monthly, Inc. v. Bullock, 489 U.S. 1, 40 (1989) (Scalia, J., dissenting) ("Where accommodation of religion is the justification, by definition religion is being singled out.").

II This definition of accommodation is not the same as Professor McConnell's. In making the case for accommodation, Professor McConnell includes both claims of right (accommodations which the Constitution obligates government to make) and appeals to political discretion. See McConnell, Accommodation, supra note 6, at 5. I am concerned only with the latter; however, he and I do agree that courts should recognize some free exercise claims as a matter of right. See Lupu, Where Rights Begin, supra note 7, at 948-53; Michael W. McConnell, Free Exercise Revisionism and the Smith Decision, 57 U. CHI. L. REv. 1109, 1144-45 (1990) [hereinafter McConnell, Revisionism]. Although both of us think that the general reasoning of Smith is constitutionally indefensible, Professor McConnell seems ambivalent about the actual result of the case. See McConnell, Revisionism, supra, at 1113 (expressing uncertainty about free exercise protection for the religious use of peyote). In addition, he embraces, and I reject, a general doctrine of church autonomy. Compare McConnell, Accommodation, supra note 6 , at 28 (claiming that "[c]hurch autonomy is a shared value of accommodationists and separatists alike") with Lupu, Religious Institutions, supra note 7, at 400-23 (arguing against recognizing religion clause rights in churches as institutions). 
designed for purposes other than aiding religion, for which religious individuals or institutions may (along with others) be eligible. Thus, the inclusion of religious schools or charities in general programs of aid is not an "accommodation" when such inclusion is based on something other than the institution's religious character.

The second element of the definition, that the claim not be one of constitutional right, may be of greater importance than the first. Of course, many accommodation claims are advanced explicitly or implicitly in the alternative. A person who believes that government should recognize conscientious objection to conscription for military service, for example, may argue that the government is obliged by the Constitution to permit objector status, and that government, in any event, should recognize such status for reasons of policy, prudence, and/or subconstitutional principle. The distinction between these arguments is crucial. When government is acting to fulfill its constitutional responsibilities or, to put it in more usual terms, to respect constitutional rights, I am emphatically for the result rather than against it. When government goes beyond what the Constitution compels, however, it is privileging religious claims in ways likely to offend constitutional norms and to reflect poor statecraft.

Thus, the zone of accommodation cannot be described without first establishing the baseline of constitutional right to exceptional treatment for religion. We must first understand what state policies the Free Exercise Clause mandates before we can begin to describe any additional state policies that may be supported by the doctrine of accommodation. Attaining such an understanding has always been difficult as a matter of positive law and is now even more challenging as a result of the Smith decision. Prior to Smith, the descriptive difficulty arose primarily from the gap between the standards the Supreme Court said it was applying and the outcome of those applications. Time after time, the Court found waystypically, exceptions to the presumptively applicable free exercise standard or unjustifiably weak applications of it-to conclude that the free exercise claim was nonmeritorious. ${ }^{12}$ After Smith, the free

12 See, e.g., Jimmy Swaggart Ministries v. Board of Equalization, 493 U.S. 378, 392 (1990) (holding that a generally applicable sales tax could be levied on a religious organization without violating the Free Exercise Clause); Hernandez v. Commissioner, 490 U.S. 680, 683-84 (1989) (holding that payments made to the Church of Scientology's branch churches for auditing and training services were not deductible charitable contributions); Lyng v. Northwest Indian Cemetery Protective Ass'n, 485 U.S. 439, 441-42 (1988) (holding that the Free Exercise Clause did not prohibit the 
exercise standard has been still further defanged. In a world in which no mandatory state policies exist, all government action beneficial to religion qua religion is above the baseline, and, therefore, presumptively within the zone of permissive accommodation.

The implications of Smith are crucial to the accommodation argument, and I address them later in the Article. Smith, however, is poor law, and I do not want to build the case against accommodation with Smith as my albatross. ${ }^{13}$ For purposes of my normative argument, therefore, it may be best simply to assert what I believe

government from timber harvesting and road construction in an area traditionally used for religious purposes by Native American tribes); O'Lone v. Estate of Shabazz, 482 U.S. 342, 345 (1987) (holding that prison security policies were not violative of the Free Exercise Clause); Goldman v. Weinberger, 475 U.S. 503, 510 (1986) (upholding, as applied to an Orthodox Jew, an Air Force regulation prohibiting the indoor use of headgear); Bob Jones Univ. v. United States, 461 U.S. 574, 602-04 (1983) (upholding the government's denial of tax benefits to a university, which, for religious reasons, prohibited interracial dating and marriage on campus); United States v. Lee, 455 U.S. 252, 261 (1982) (upholding the imposition of social security tax on an Amish employer). See generally Robert D. Kamenshine, Scrapping Strict Review in Free Exercise Cases, 4 CONST. COMMENTARY 147, 154 (1987) (arguing that the Court should make explicit that a middle tier standard rather than a strict review standard is appropriate in adjudicating free exercise claims); Perry Dane, Note, Religious Exemptions Under the Free Exercise Clause: A Model of Competing Authorities, 90 YALE L.J. 350 (1980) (criticizing "current exemption doctrine" and proposing an alternative system of decision for religion-based exemptions); Developments in the LawReligion and the State (pt. V), 100 HARV. L. REV. 1606, 1703-15 (1987) [hereinafter Developments in the Law] (discussing religious exemptions under the Free Exercise Clause).

${ }^{13}$ Smith has been widely criticized. See, e.g., James D. Gordon III, Free Exercise on the Mountaintop, 79 CAL. L. REv. 91, 91 (1991) (arguing that the Smith decision "mistreated precedent, used shoddy reasoning, and ... deprived the free exercise clause of any independent significance"); Douglas Laycock, The Remnants of Free Exercise, 1990 SUP. CT. REV. 1 [hereinafter Laycock, Remnants] (criticizing Smith); Lupu, supra note 4 (manuscript at 17-28, on file with author) (criticizing Smith); McConnell, Revisionism, supra note 11, at 1111 (arguing that Smith is contrary to the "deep logic of the First Amendment"); Harry F. Tepker, Jr., Hallucinations of Neutrality in the Oregon Peyote Case, 16 AM. INDIAN L. REv. 1, 1 (1991) (maintaining that the Smith decision "distort[s] precedents" and undermines individual liberty). But see William P. Marshall, The Case Against the Constitutionally Compelled Free Exercise Exemption, 40 CASE W. REs. L. REv. 357, 386-412 (1989-1990) [hereinafter Marshall, Case Against] (arguing against religion-based exemptions); William P. Marshall, In Defense of Smith and Free Exercise Revisionism, 58 U. CHI. L. REv. 308, 308-09 (1991) [hereinafter Marshall, Defense] (defending the outcome in Smith, but not the opinion itself); Ellis West, The Case Against a Right to Religion-Based Exemptions, 4 NoTRE DAME J.L. ETHICs \& PUB. POL'y 591, 633-38 (1990) (same); Philip A. Hamburger, A Constitutional Right to Religious Exemptions: An Historical Perspective 3-19 (May 1991) (unpublished manuscript, on file with author) (arguing that constitutional history does not support the concept of exemptions). 
the Free Exercise Clause requires of the government. First, the clause prohibits the government from singling out religion for especially bad treatment. ${ }^{14}$ This prohibition includes overt mistreatment of religion-for example, the outlawing of taking communion, performing ritual circumcision, or praying to idols-as well as actions taken out of covert hostility, such as a zoning board acting solely out of religious animus in denying permission to a group seeking official permission to build a church in a particular place. Political decisions that intentionally disfavor religion violate the Free Exercise Clause, unless these decisions are mandated by the Establishment Clause. ${ }^{15}$

Second, and far more controversially, I believe, contrary to Smith, that the Free Exercise Clause protects a limited class of claims for religious exemption from laws of general applicability. Although it is difficult to articulate the scope and limits of this doctrine in a single phrase, I believe it presumptively protects claims to refrain from actions which the claimant sincerely believes on religious grounds will be deeply wrong to commit and claims to

${ }^{14}$ The Smith opinion embraces this view. See Smith, 110 S. Ct. at 1599 (1990) (stating that states may not ban "acts or abstentions only when they are engaged in for religious reasons, or only because of the religious belief that they display"). Church of the Lukumi Babalu Aye v. City of Hialeah, 723 F. Supp. 1467 (S.D. Fla. 1989), affd, 936 F.2d 586 (11th Cir. 1991), offers an intriguing and difficult variation on this theme. In Hialeah, the court upheld city ordinances regulating the ritual slaughter of animals despite the city's apparent motivation to eliminate the practices of one particular religion. See Hialeah, 723 F. Supp. at 1483-88. Professor Laycock, counsel to the Church on appeal, discusses the case further in Laycock, Remnants, supra note 13 , at $66-68$.

${ }^{15}$ See McDaniel v. Paty, 435 U.S. 618, 628-29 (1978) (invalidating, on Free Exercise Clause and Establishment Clause grounds, a Tennessee constitutional provision that barred ministers from serving as legislators). Occasionally, prison officials act in ways that intentionally disfavor religious exercise claims of inmates; all too often, and quite mistakenly, courts treat such claims as identical to those involving incidental burdens on religion generated by religion-neutral prison regulations. See, e.g., Hadi v. Horn, 830 F.2d 779, 784-88 (7th Cir. 1987) (holding that occasional cancellation of Muslim prison services when chaplain was not available and when chapel was needed for recreational purposes did not violate inmates' First Amendment rights); Allen v. Toombs, 827 F.2d 563, 566-68 (9th Cir. 1987) (holding that prison policy of prohibiting inmate access to "Sweat Lodge" for exercise of religion was not unconstitutional and that prohibiting inmates from conducting pipe ceremony did not violate inmates' First Amendment rights); Brown v. Johnson, 743 F.2d 408, 412-13 (6th Cir. 1984) (upholding prison ban on group worship service of church that ministered to the spiritual needs of homosexual prisoners), cert. denied, 469 U.S. 1215 (1985); see also Geoffrey S. Frankel, Note, Untangling First Amendment Values: The Prisoners' Dilemma, 59 GEO. WASH. L. REV. 401, 432 (1991) (arguing for strict review in cases involving the direct regulation of the religious practices of prison inmates). 
engage in actions which the claimant sincerely believes on religious grounds will be deeply wrong to omit. Such claim of conscience are privileged unless the state can successfully assert that exempting the behavior will cause actual and substantial harm to significant state interests. ${ }^{16}$

This conception of free exercise, and the rather limited zone of mandatory rights it generates, leaves open an expansive zone of potential accommodation. Many religious customs and practices have significance to religious people and institutions. Unless we are prepared to make religious claimants judges in their own cause-a status our law ordinarily does not confer on parties-the state's judges will have to decide which religious claims are sufficiently pressing to qualify as matters of right. Under any such process of decision, decisionmakers will quite reasonably perceive many claims as falling short of the requirement of "deep wrongs" to which the clause may be limited. For example, practices which have become customary within a religious community, yet in no way appear to be the result of scriptural, theological, or other command, may not be of sufficient moment to support a free exercise exemption from laws of general applicability. ${ }^{17}$ For still other claims, courts may

${ }^{16}$ I elaborate on the themes expressed in this paragraph and add concerns for legal procedure and the special role of religious institutions in Lupu, supra note 4. I do not pretend that the judgments mandated by any sensible theory of free exercise adjudication are easy to make or uncontroversial. As a general proposition, however, there appear to be only three basic choices: (1) no free exercise exemptions should be granted, (2) all claimed free exercise exemptions should be granted, or (3) all free exercise claims should be tested against a standard which measures, among other things, their religious properties and the state's competing concerns. I reject (1), and (3) seems far more appealing and prudent than (2). See Lupu, Where Rights Begin, supra note 7, at 952-53 (arguing that free exercise standards must avoid extremes).

When free exercise rights overlap with free speech or press rights-that is, when what is being regulated is expression, including religious expression-concerns unique to the Free Exercise Clause may not add significantly to the constitutional analysis. See, e.g., Cantwell v. Connecticut, 310 U.S. 296, 307-11 (1940) (relying on general principles of freedom of expression, as applied to religious speech, to set aside a conviction of Jehovah's Witnesses who were soliciting in violation of a statute). For the argument that the Free Exercise Clause should be held to do no more than the clauses protecting freedom of expression, see Marshall, Case Against, supra note 13, at 394-98; William P. Marshall, Solving the Free Exercise Dilemma: Free Exercise as Expression, 67 MINN. L. REV. 545 (1983) [hereinafter Marshall, Solving].

${ }^{17}$ This is one of the reasons that Wisconsin v. Yoder, 406 U.S. 205 (1972), which upheld the right of the Amish to educate their children at home, may have been incorrectly decided. The practice protected in Yoder-removing adolescent children from the public schools at age 14-was defined by the Court almost entirely on communitarian rather than religious grounds. Although the right of association may support some communitarian claims which arise from religious communities, I would 
agree on their religious significance yet conclude that the state's case for the imperative character of non-exemption is overpowering. Claims that are viewed as religiously trivial and claims that might appear to judges to be trumped by insurmountable concerns of state policy are candidates for permissive accommodation.

In addition, state policy governing the "business behavior" of private institutions-for example, in matters of fund-raising, employment, and taxation-may create impediments to freedom of action by religious entities. ${ }^{18}$ Efforts to relieve these burdens also fall into the accommodation category, although these matters may not implicate religious precepts at all. Exempting religious organizations from property taxation, for example, makes organizational activity less expensive and complex, whether or not the organization's members have religious commitments against the payment of taxes.

Accommodation is an important subject these days not only because its potential scope is far-reaching. The law respecting voluntary accommodation of religion by government is unstable and open to capture. Notwithstanding the dicta in Smith regarding the appropriateness of voluntary accommodation, the Supreme Court's two most recent and direct tussles with the topic-Corporation of the Presiding Bishop of the Church of Jesus Christ Latter-Day Saints v. $A \operatorname{mos}^{19}$ and Texas Monthly, Inc. v. Bullock ${ }^{20}$-reveal substantial uncertainty within the Court's current membership concerning the scope of permissible accommodations. ${ }^{21}$

not extend associational rights to parental claims made on behalf of children. Once free exercise and associational rights claims are removed in Yoder, all that remains is the authoritarian claim of parental control over the rearing of children. Based on the facts in Yoder, I do not think that claim is weighty enough to surmount the combined interest of state and children that the latter's formal education proceed.

For a sharply divergent view on the significance of religious command versus custom, see Laycock, Remnants, supra note 13, at 24-26 (questioning the notion that the Free Exercise Clause should protect only religious mandates and excludes religious custom from protection).

${ }^{18}$ See Douglas Laycock, Towards A General Theory of the Religion Clauses: The Case of Church Labor Relations and the Right to Church Autonomy, 81 CoLUM. L. REV. 1373, 1409-12 (1981) [hereinafter Laycock, Church Labor Relations] (discussing how some church-owned businesses are run for religious reasons and are, therefore, affected by government regulation); see also Angela C. Carmella, A Theological Critique of Free Exercise Jurisprudence, 60 GEO. WASH. L. REV. (forthcoming Mar. 1992) (manuscript at 13-23, on file with the author) (discussing how government regulation can burden religion).

${ }_{19} 483$ U.S. 327 (1987).

20489 U.S. 1 (1989).

${ }^{21}$ Several decisions rendered earlier in the 1980 s had suggested a relatively hard 
In Amos, decided in 1987, a Court unanimous as to result rejected an Establishment Clause attack on the exemption for religious organizations from the federal prohibition on religious discrimination in employment. Although Amos produced several concurring opinions, they were primarily focused on the question of confining the holding to nonprofit enterprises. In Texas Monthly, a divided (6-3) Court invalidated, on Establishment Clause grounds, an exemption from a state sales tax scheme for religious periodicals "published or distributed by a religious faith." ${ }^{22}$

As Justice Scalia argued strenuously in dissent, Texas Monthly sends a very different signal concerning voluntary accommodation than does Amos. Both cases involved statutory relief for religious organizations from burdens of regulation or taxation. In Texas Monthly, the Court struck down the exemption because it failed to include secular periodicals. In Amos, the Court never suggested that nonreligious associations might have analogous exemption claims. ${ }^{23} A m o s$ rests in part on the legislative decision to relieve religious organizations from burdens which the Free Exercise Clause may prohibit. ${ }^{24}$ Yet that argument, arguably stronger in the state tax context, was insufficient in Texas Monthly to save the scheme. ${ }^{25}$

The different outcomes in the two cases can no doubt be explained in a number of respects. The arguable underinclusion of the discrimination exemption was not under direct challenge in Amos; the complainants were dismissed employees who wanted the exemption invalidated, not extended. In addition, Texas Monthly relied in part on the Press Clause of the First Amendment and its implicit prohibition of content discrimination in the dispensing of tax exemptions relating to reading materials. ${ }^{26}$ Nevertheless, the

line against permissive accommodations. See Estate of Thornton v. Caldor, Inc., 472 U.S. 703, 710-11 (1985) (invalidating a state statute which required employers to accommodate employees' Sabbath designations); Larkin v. Grendel's Den, Inc., 459 U.S. 116, 117-20 (1982) (invalidating a state law that effectively authorized schools and churches to veto liquor license grants to nearby premises).

${ }^{22}$ Texas Monthly, Inc., 489 U.S. at 5.

${ }^{23}$ For example, organizations devoted to the interests of women might prefer to hire only females-a preference upon which the statute forbids them from acting.

${ }^{24}$ See Amos, 483 U.S. at 338.

${ }^{25}$ Over Justice Scalia's strenuous protest in dissent, Justice Brennan, in Texas Monthly, distinguished the sales tax from the occupational or license tax, see Texas Monthly, Inc. 489 U.S. at 24, which the Court had previously established could not be applied to the activity of itinerant preachers. See, e.g., Follett v. Town of McCormick, 321 U.S. 573, $577-78$ (1944) (invalidating a flat tax as applied to preachers); Murdock v. Pennsylvania, 319 U.S. 105, 116-17 (1943) (invalidating a flat license tax as applied to Jehovah's Witnesses).

${ }^{26}$ Justices White, Blackmun, and O'Connor all concurred in the Texas Monthly 
intensity of Justice Scalia's Texas Monthly dissent, joined by Justice Kennedy and the Chief Justice, suggests that members of the Court are deeply divided over the question of voluntary accommodations. The departure of Justices Brennan and Marshall, and the uncertainty of church-state views held by Justices Souter and Thomas, further beclouds the picture.

This mystery is no doubt part and parcel of the general uncertainty that has afflicted Establishment Clause adjudication of late. The Establishment Clause "test" advanced in Lemon $v$. Kurtzman ${ }^{27}$ has been ignored in significant contexts ${ }^{28}$ and has been highly criticized by judges and commentators, primarily on the ground of insensitivity to original principles. ${ }^{29}$ I share this view of the "test," and I believe, in any event, that it is about to be interred. $I$, therefore, now turn to the first principles that must underlie any adjudicative approach to the religion clauses.

decision, and all relied on Arkansas Writers' Project v. Ragland, 481 U.S. 221, 234 (1987), which invalidated on Press Clause grounds a sales tax exemption for trade publications, sports magazines, religious periodicals and sacred writings. See Texas Monthly, Inc., 489 U.S. at 26 (White, J. concurring); id. (Blackmun, J. concurring, opinion joined by O'Connor, J.), see also Grosjean v. American Press Co., 297 U.S. 233, 251 (1936) (invalidating, on Press Clause grounds, a tax that was based on the extent of a publication's circulation).

27403 U.S. 602 (1971). In order to satisfy Lemon, a statute must meet a three part test: (1) "the statute must have a secular legislative purpose," (2) the primary effect of the statute must "neither advance[] nor inhibit[] religion," and (3) "the statute must not foster 'an excessive government entanglement with religion." Id. at 612-13 (citations omitted).

${ }^{28}$ See, e.g., Lynch v. Donnelly, 465 U.S. 668, 687 (1984) (failing to apply Lemon to public support of a Nativity Scene); Marsh v. Chambers, 463 U.S. 783, 792-95 (1983) (failing to apply Lemon to legislative prayer).

${ }^{29}$ See, e.g., County of Allegheny v. ACLU, 492 U.S. 573, 655-56 (1989) (Kennedy, $\mathrm{J}$., concurring in the judgement in part and dissenting in part) (pointing out that "[p]ersuasive criticism of Lemon has emerged"); Wallace v. Jaffree, 472 U.S. 38, 108-12 (1985) (Rehnquist, J., dissenting) (arguing that the Lemon test has "not provided adequate standards for deciding Establishment Clause cases"); Benjamin D. Feder, And a Child Shall Lead Them: Justice O'Connor, The Principle of Religious Liberty and Its Practical Application, 8 PACE L. REV. 249, 271, 296-300 (1988) (criticizing the Lemon test and proposing modifications to its application); Laycock, Church Labor Relations, supra note 18, at 1380-88 (criticizing the Lemon test); Lupu, Keeping the Faith, supra note 7 , at 752 (criticizing the "effects focus" of the Lemon test); Michael A. Paulsen, Religion, Equality, and the Constitution: An Equal Protection Approach to Establishment Clause Adjudication, 61 NOTRE DAME L. REV. 311, 315-17 (1986) (same); Gary J. Simson, The Establishment Clause in the Supreme Court: Rethinking the Court's Approach, 72 CORNELL L. REV. 905, 910-11, 923-35 (1987) (proposing significant reforms to the Lemon test). But see Daniel O. Conkle, Toward a General Theory of the Establishment Clause, 82 Nw. U. L. REv. 1113, 1172-82 (1988) (defending the Lemon test). 


\section{The Purposes of the Religion Clauses}

The accommodationist thesis depends on an artificial compression of the constitutional ends of the religion clauses. Indeed, this generation's best known essay on the subject of accommodation begins with the statement: "It is sometimes forgotten that religious liberty is the central value and animating purpose of the Religion Clauses of the First Amendment." ${ }^{\text {30 }}$ Accommodationists tend to treat the Establishment Clause as a quaint relic, a secondary (and slightly anachronistic) reflection of the constitutional goal of religious liberty. ${ }^{31}$

The religion clauses have multiple purposes, all of presumptively equal constitutional importance. Accommodationists are of course correct that these goals include the protection of religious liberty from state infringement. Accommodationists and separationists alike hold that the state should not coerce religious choices. The accommodationist argument, however, stops much too soon. As Professor McConnell and virtually all other commentators and judges concede, the religion clauses forbid sectarian discrimination. ${ }^{32}$ But why? The principle of religious liberty taken alone is insufficient to fully justify an antidiscrimination principle, especially if the principle applies to the provision of benefits. At this point, the religion clauses' second animating concern-that of equal religious liberty-must be brought into play. In a regime of equal religious liberty, the state must treat all approaches to religion with equal respect. ${ }^{33}$

${ }^{30}$ McConnell, Accommodation, supra note 6, at 1.

31 See, e.g., Richard J. Neuhaus, A New Order for the Ages, 60 GEO. WASH. L. REv. (forthcoming 1992) ("The no-establishment part of the religion (sic) clause is entirely and without remainder in the service of free exercise."). Professor McConnell's most recent work, moreover, strongly suggests that he continues to support marginalizing the Establishment Clause. See his The Selective Funding Problem: Abortions and Religious Schools, 104 HARV. L. REV. 989, 992-93 (1991), in which Professor McConnell likens, for constitutional purposes, government refusal to fund abortions with government refusal to fund parochial schools. The essay, while provocative and worthwhile in a number of respects, will surprise most constitutional lawyers with its relative inattention to any basic theory of the Establishment Clause.

${ }^{32}$ See Wallace, 472 U.S. at 106, 113 (Rehnquist, J., dissenting); McConnell, Accommodation, supra note 6, at 39.

${ }^{39}$ See Lupu, Keeping the Faith, supra note 7, at 740 (arguing that principles of equality should govern Establishment Clause cases); see also Alan E. Brownstein, Harmonizing the Heavenly and Earthly Spheres: The Fragmentation and Synthesis of Religion, Equality, and Speech in the Constitution, 51 OHIO ST. L.J. 89, 91 (1990) (arguing that interpretation of the religion clauses can be rendered more intelligible by analogizing their meaning to equal protection doctrine); Paulsen, supra note 29, 
The goals of religious liberty and equal religious liberty correspond rather well with the "origin[s] and the line of ... growth"34 of the two religion clauses in the First Amendment. The prohibition on laws respecting establishment ${ }^{35}$ is primarily an equal liberty provision; only secondarily is it concerned with religious liberty in a noncomparative sense. An established church has unfair competitive advantages over its rivals. Establishments may rely on the state to compel attendance and provide financial support. Moreover, as Adam Smith argued in Wealth of Nations, ${ }^{36}$ which was published in 1776 and well known among American constitution-makers, an established church may invoke state power to suppress religious dissent, and may otherwise undermine religious equality. ${ }^{37}$ Echoing Adam Smith, James Madison argued

at 325 ("[T]he Establishment Clause is best understood as providing for the equal protection of the free exercise of religion."); David E. Steinberg, Religious Exemptions as Affirmative Action, 40 EMORY L.J. 77, 79 (1991) (suggesting that the Court should authorize the use of religious exemptions to accommodate members of minority religious groups as a form of affirmative action).

${ }^{34}$ Gompers v. United States, 233 U.S. 604, 610 (1914) (citing Robertson v. Baldwin, 165 U.S. 275, $281-82$ (1897) (Holmes, J.)).

${ }^{35}$ As originally framed and ratified, the Establishment Clause, which proscribes laws "respecting establishment," served federalism purposes as well as religious liberty purposes. The clause guaranteed the states (as well as the people) that the federal government would neither establish a national church nor legislate against existing state establishments. See generally Joseph M. Snee, Religious Disestablishment and the Fourteenth Amendment, 1954 WASH. U. L.Q. 371, 372-73 (arguing that the Establishment Clause and the Free Exercise Clause must be distinguished and that the former cannot be incorporated into the liberty interests protected by the Fourteenth Amendment). The demise of state establishments in the early 18th century, however, eliminated the explicit state-protecting purpose of the Establishment Clause. Moreover, the application of the Establishment Clause to the states, by the process of incorporation into the Fourteenth Amendment, reinforces the character of the contemporary Establishment Clause as a rights-bearing clause. See Everson v. Board of Educ., 330 U.S. 1, 15-16 (1947).

Further, it is virtually impossible to argue, in terms of original intent, that the Free Exercise Clause applies to the states but that the Establishment Clause does not. The clauses are part of the same sentence, deal with the same subject, and represent complementary parts of an overall constitutional strategy for dealing with the problem of religion and government. Thus, the clauses must either rise or fall together in their application to the states. If the case for incorporation fails, the Fourteenth Amendment, standing alone, would exhibit greater Establishment Clause characteristics than it would Free Exercise Clause traits; the Equal Protection Clause is a more generalized version of the religious equality command, and the Due Process Clause (given its procedural character) cannot easily be transubstantiated into a fount of religious liberty.

36 ADAM SMITH, AN INQUIRY INTO THE NATURE AND CAUSES OF THE WEALTH OF NATIONS (Edwin Cannan ed., Modern Library 1937) (1776).

${ }^{37} \mathrm{See} i d$. at 741 (observing that established clergy may, in an emergency, "call 
in his famous Memorial and Remonstrance Against Religious Assessments that churches supported by compulsory taxation need not depend, as do others supported voluntarily, on the persuasiveness of their message or the skill of their leaders in maintaining a following. ${ }^{38}$

More subtly, the identification of a church with state power reduces the dissonance between the claims of religion and those of nationalism. A church with such a link benefits from a reduction of competing loyalties, which otherwise might make the church less appealing to the populace. ${ }^{39}$ Constitutional prohibition of an established church, and of more subtle acts of government sponsorship of religion, advances equal liberty to make choices respecting religion by eliminating a crucial source of sectarian advantage.

Such a prohibition, however, only secondarily protects religious liberty itself. A nonestablishment principle does not protect any one religion against a surge of governmental hostility toward all religions. ${ }^{40}$ Thus, quite appropriately, the second religion clause protects religious liberty directly by proscribing laws that "prohibit[] the free exercise of religion. ${ }^{41}$ This clause creates the foundation for the two basic principles, sketched above, of free exercise: (1) that no acts of direct hostility by government against religion are allowed; and (2) that exemptions from general laws for religiously motivated conduct are sometimes required.

The task of constitutional interpretation of the religion clauses is to recall and maintain both of these goals, despite the occasional tension between them. The tension arises at the boundary between

upon the civil magistrate to persecute, destroy, or drive out their adversaries, as disturbers of the public peace"); $i d$. at 744 (arguing that religious sects which allied with conquering political factions were "soon enabled in some degree to silence and subdue" their adversaries). Smith also argued that established churches were at a disadvantage, because their clergy tended to become indolent, and lose religious zeal, id. at 741, and that nonestablishment would promote both equality and multiplicity of sects as well as harmony among them, id. at 744-46.

38 JAMES MADISON, MEMORIAL AND REMONSTRANCE AGAINST RELIGIOUS ASSESSMENTS (1785), reprinted in Everson, 330 U.S. at 67-68 (app. to opinion of Rutledge, J., dissenting).

${ }^{39}$ See Robert N. Bellah, Civil Religion in America, 117 DaEdalus 97-118 (1988); John Webster Grant, 'At Least You Knew Where You Stood With Them': Reflections on Religious Pluralism in Canada and the United States, in 2 STUDIES IN RELIGION 340, 343 (1973); Robert T. Handy, The Protestant Quest for a Christian America, in XXII CHURCH HISTORY 8, 11-12 (J. H. Nichols \& Wilhelm Pauck eds., 1953).

40 Professor Laycock has advanced a similar view in his criticism of Smith: "The extreme case of substituting equality rights for substantive rights would be total suppression of all religions." Laycock, Remnants, supra note 13, at 13.

41 U.S. CONST. amend. I. 
religion and nonreligion; the Free Exercise Clause suggests the privileging of religion over nonreligion, whereas the Establishment Clause suggests the normative equality of the two. Nevertheless, interpretation need not advance one of the goals at the expense of the other or, more aggressively, seek to drive one of the goals underground. As in other cases of intra-constitutional conflict, ${ }^{42}$ the goals of the respective provisions should be distinctly maintained and conflicts between them resolved with attention and respect to all competing values.

\section{THE IMPACT OF EMPLOYMENT DIVISION, DEPARTMENT OF HUMAN RESOURCES V. SMITH}

In April of 1990, the Supreme Court announced its decision in Employment Division, Department of Human Resources $v$. Smith. ${ }^{43}$ The sweep and grounds of the decision stunned constitutional lawyers and commentators ${ }^{44}$ and profoundly altered the backdrop of principles against which the accommodation debate is played out.

The case arose from the denial of unemployment compensation benefits to two members of the Native American Church. Because they had ingested peyote at a Church ceremony, the two had been dismissed from positions as counselors in a private entity devoted to rehabilitation of persons addicted to drugs or alcohol. ${ }^{45}$ The relevant state agency denied them benefits under a state law provision disqualifying persons dismissed for work-related misconduct. ${ }^{46}$ The state court reversed the state agency's decision, reasoning that the disqualification impermissibly burdened the petitioners' rights under the Free Exercise Clause. ${ }^{47}$

The state successfully petitioned the U.S. Supreme Court for review. In a little noticed and highly questionable decisional maneuver, the Court vacated the judgment and remanded the case to the courts of Oregon for a determination of whether peyote use violates the state's criminal law. ${ }^{48}$

42 Conflicts between free press and fair trial protections present a comparable example. See Nebraska Press Ass'n v. Stuart, 427 U.S. 539, 547 (1976).

43110 S. Ct. 1595 (1990).

44 See sources cited supra note 13.

${ }^{45}$ See Smith, 110 S. Ct. at 1597.

${ }^{46}$ See id. at 1598.

${ }^{47}$ See id.

${ }^{48}$ See Employment Div., Dep't of Human Resources v. Smith, 485 U.S. 660, 673-74 (1988). Several reasons lead me to question the propriety of the remand for these purposes. First, there was nothing in preexisting free exercise case law to suggest that 
On remand, the Oregon Supreme Court held that the state's criminal law included a general prohibition on peyote possession and use but that Native American Church members were privileged by the Free Exercise Clause against criminal conviction for peyote use in religious ceremonies. ${ }^{49}$ This conclusion enabled the state court to reaffirm that the Free Exercise Clause forbade the state from treating the petitioners' peyote use as disqualifying them from unemployment insurance benefits. ${ }^{50}$

The state authorities once again obtained Supreme Court review. This time, however, the Supreme Court relied on the state court's view concerning the criminal law status of peyote use to reverse the state court's judgment about the free exercise claim. In an opinion that swept far beyond what was necessary to rule in the state's favor, ${ }^{51}$ the Court announced a general principle that the Free Exercise Clause standing alone would never entitle religiously motivated conduct to a judicially created exemption from state

the criminal law treatment of the activity for which constitutional privilege was sought was of special relevance. Second, and quite simply, Smith and Black had not been criminally charged for peyote use; it was entirely possible that their conduct was privileged against an adverse application of unemployment compensation principles but was not similarly privileged against an application of stronger state purposes reflected in its criminal law. Third, as revealed in the Smith opinion in 1990, the remand simply provided a foundation, albeit highly questionable, for treating this case as a request for constitutional exemption from a law of "general applicability" rather than as a claim that "work-related misconduct" could not include constitutionally privileged activity. Smith, $110 \mathrm{~S}$. Ct. at 1599 . This latter version of the claim far more accurately and less tendentiously describes it and had more than ample support in Supreme Court precedent. See McConnell, Revisionism, supra note 11, at 1111-12 (arguing that the state court's holding that Oregon may not "treat the exercise of religious practices as 'misconduct' warranting denial of otherwise available benefits," appears to be an unexceptional application of well-established precedent).

${ }^{49}$ See Smith v. Employment Div., Dep't of Human Resources, 763 P.2d 146, 148 (Or, 1988), rev'd, 110 S. Ct. 1595 (1990).

${ }^{50}$ See id. at 149-50.

51 Justice O'Connor's concurrence concluded that the peyote users' claim in this case was insufficient in light of preexisting free exercise standards; she, therefore, criticized the majority for so aggressively and unnecessarily altering the law. See Smith, $110 \mathrm{~S}$. Ct. at 1606 (O'Connor, J., concurring in the judgment). The dissent's view, which similarly criticized the majority's general approach but reached a different conclusion about the constitutionally privileged character of the claim, is far more persuasive than Justice O'Connor's opinion. Only the dissent articulates and applies normatively appropriate standards. See id. at 1615-23 (Blackmun, J., dissenting). Justice O'Connor, however, may have been correct in her appraisal of the Court's recent attitude toward free exercise claims. See generally Kamenshine, supra note 12, at 147 (arguing that although the Court purports to apply strict scrutiny to regulations adversely affecting religious freedom, it effectively applies a less heightened standard that it should acknowledge). 
criminal laws of general applicability. Although written by Justice Scalia, the leading proponent on the Court of judicial reliance on the original meaning of the text, ${ }^{52}$ the opinion simply ignores the circumstances surrounding the adoption of the Free Exercise Clause. Nor does the opinion even faintly attempt to parse the Clause's text. 53

The Court's new principle apparently derives instead from two related sources. The first is a substantive concern for legal stability and predictability. The Court avowedly fears the "anarchy" that would result from permitting religion-based exemptions from general laws. ${ }^{54}$ The second is institutional, and reflects doctrines of judicial restraint. The Smith opinion expresses horror at the prospect, implicit in the pre-Smith law, "that federal judges will regularly balance against the importance of general laws the significance of religious practice. ${ }^{55}$ Neither the substantive nor the institutional bases for Smith can be limited to the criminal law, and the lower courts have thus far made no attempt to confine it to that field. ${ }^{56}$

52 See Antonin Scalia, Originalism: The Lesser Evil, 57 U. CIN. L. REV. 849, 862 (1989). Justice Scalia's defense of originalism does not mesh with institutional circumstance; members of the Supreme Court have neither the time nor the professional skills to engage in systematic historical research. When the professed decisionmaking method does not fit the decisionmaking process or the personnel, something gives. In Smith, to a far greater extent than usual, the professed method vanished.

${ }^{53}$ At the very least, the use of the word "exercise" should occasion a reflective pause. See generally McConnell, Origins, supra note 6, at 1414-16 (analyzing various sources to determine the probable understanding of the drafters and ratifiers of the Free Exercise Clause).

54 See Smith, 110 S. Ct. at 1605.

${ }^{55}$ Id. at 1606 n.5.

56 See Salvation Army v. New Jersey Dept. of Community Affairs, 919 F.2d 183, 194-96 (3rd Cir. 1990) (holding that the Supreme Court's decision in Smith is applicable to civil as well as criminal statutes); Rector, Wardens, and Members of the Vestry of St. Bartholomew's Church v. City of New York, 914 F.2d 348, 354 (2nd Cir. 1990) (holding, in light of Smith, that the application of New York's Landmarks Law to the church's property did not violate its right to the free exercise of religion), cert. denied, 111 S. Ct. 1103 (1991); Calderon v. Witvoet, 764 F. Supp. 536, 541 (C.D. Ill. 1991) (holding, in light of Smith, that requiring an employer to obtain insurance, as required under a migrant workers law, did not violate the employer's free exercise of religion); United States v. Philadelphia Yearly Meeting of the Religious Soc'y of Friends, 753 F. Supp. 1300, 1304 (E.D. Pa. 1990) (holding, in light of Smith, that levies upon delinquent income taxes, owed by employees of a Quaker organization refusing to pay the portion of their taxes allocable to military purposes, did not violate the Free Exercise Clause); Yang v. Sturner, 750 F. Supp. 558, 559 (D.R.I. 1990) (withdrawing, in light of Smith, an earlier opinion that had required an exemption for members of the Hmong religious sect from the Rhode Island law governing 
Finally, and of central significance to the question of permissive accommodation, the Court in Smith suggested that legislatures, unlike courts, could single out and especially protect religiously motivated conduct. ${ }^{57}$ In particular, the Smith majority suggested the appropriateness and permissibility of a legislatively drawn exemption from the criminal prohibition on peyote use for members of the Native American Church. ${ }^{58}$ Smith's institutional concerns may be paramount to its substantive ones. ${ }^{59}$ In this view, special legislative treatment for religion-indeed, for particular sects-is not a matter of constitutional worry; only judicially mandated special treatment is forbidden by the Constitution. Legislatively granted exemptions no longer represent presumptively impermissible favoritism for religion. According to Smith, such exemptions are the democratic process doing its work. ${ }^{60}$

In two powerfully important respects, Smith has altered the landscape of accommodation. First, as a substantive matter, it has made virtually all special and positive treatment of religion a matter of political discretion, rather than a matter of constitutional right. Courts are essentially removed from the business of protecting religion from the incidental burdens inflicted by general laws. Only the political branches of government remain free to do anything designed to create a positive and special benefit for religion, and Smith invites them to do it. With a vengeance, Smith elevates

autopsies).

In addition, the Court in Smith distinguished prior Supreme Court decisions upholding free exercise claims in such a way as to cast doubt on the continuing validity of those decisions and to undermine the independent importance of the Free Exercise Clause in constitutional adjudication. See generally Gordon, supra note 13, at 94-104 (criticizing the Court's efforts to distinguish pre-Smith decisions that would have required the application of the "compelling interest test"); Laycock, Remnants, supra note 13 (criticizing the theoretical conceptions behind Smith and examining the practical and doctrinal impact of the Smith decision); McConnell, Revisionism, supra note 11 (criticizing the Smith Court's theoretical argument as well as its use of legal text, history, and precedent).

57 See Smith, 110 S. Ct. at 1606.

58 See id.

${ }^{59}$ Smith "officially" announces that henceforth courts should underenforce the Free Exercise Clause and leave most of the implementation of religion clause norms to the political branches. For exploration of the notion that Smith can be fit into general notions of nonjusticiability, or that issues arising under the Free Exercise Clause will henceforth present "political questions," see Lupu, supra note 4. For a general discussion of the legitimacy, propriety, and significance of judicial underenforcement, see Lawrence G. Sager, Fair Measure: The Legal Status of Underenforced Constitutional Norms, 91 HARV. L. REv. 1212 (1978).

60110 S. Ct. at 1606. 
concerns of separation of power and judicial restraint over established notions of judicial responsibility for the protection of constitutional rights.

By writing courts out of, and all other branches into, the accommodation process, Smith eliminates constitutional compulsion from the field and replaces it with political discretion to respond to the special claims of religion. ${ }^{61}$ The zone of accommodation has thus grown wider and perhaps more permissive than at any time in the past thirty years. The scope of such accommodation is crucial to religious persons and institutions seeking to advance claims of religious exemption, because they are now directed to turn exclusively to nonjudicial bodies for redress.

\section{Clearing THE Decks}

Two arguments, frequently advanced in discussion of the respective roles of the religion clauses, must be briefly confronted prior to making the case-in-chief against accommodation. The first of these has to do with the assertion of irreconcilable conflict between the religion clauses; if such conflict exists, it is sometimes argued, it must be dissolved in light of the overarching value of religious liberty. ${ }^{62}$ The second of these has to do with the role of coercion in the law of the Establishment Clause; in order both to diminish the scope of the Establishment Clause and to accentuate the relative importance of the Free Exercise Clause, accommodationists insist that coercion is an essential element of an Establishment Clause violation. Both of these moves should be resisted.

\section{A. Resolving the Clause Conflict}

The view has been advanced that the religion clauses are on a collision course; ${ }^{63}$ the very same practices that the Free Exercise Clause demands of government are simultaneously forbidden by the Establishment Clause. ${ }^{64} \mathrm{~A}$ common illustration is the question of conscientious objector status for those opposed on religious grounds to participation in war. ${ }^{65}$ Such status seems compelled by

61 See Gordon, supra note 13, at 111 (arguing that eliminating constitutional compulsion will tend to reduce the frequency of legislative exemptions).

62 See McConnell, Accommodation, supra note 6, at 6.

${ }^{63}$ See Walz v. Tax Comm'n, 397 U.S. 664, 668-69 (1970); Jesse H. Choper, The Religion Clauses of the First Amendment: Reconciling the Conflict, 41 U. PITT. L. REV. 673, 673 (1980).

64 See Choper, supra note 63 , at 674.

${ }^{65}$ See, e.g., Gillette v. United States, 401 U.S. 437, 448-54 (1971) (holding that 
free exercise, but granting such status to religious over purely moral claims is thought to benefit religion and therefore to establish it. ${ }^{66}$ An interpretation that produces such a result is to be avoided, for reasons ranging from the coherence of constitutional principles concerning religion to a larger concern for the integrity of constitutional interpretation. One way to avoid the conflict is to apply an overarching constitutional norm-the government's obligation to remedy or avoid violations of the rights of particular individuals has priority over general limits on government power. To borrow an example from race relations law, the government may reserve particular opportunities for African-Americans if there has been a sufficient finding that African-Americans have been wrongfully denied those opportunities. ${ }^{67}$ The same government action, however, may violate constitutional norms of racial equality if taken without the predicate of prior violation. ${ }^{68}$

Government action which affords special treatment on the basis of religion is highly similar. If that treatment is designed to remedy a pre-existing violation of the Free Exercise Clause or to avoid what would be a violation of that clause, it is constitutionally appropriate. If there is no such predicate, the same action violates norms of religious equality and is impermissible. ${ }^{69}$

This sort of reconciliation of the religion clauses allows for full recognition of free exercise rights. It does not, however, stand for the larger proposition that whatever advances the religious liberty of some is consistent with the religion clauses. Free exercise rights trump Establishment Clause limits, but free exercise "values" do not, because of the impact on religious equality and the religious liberty of others that would be the result of such a general favoring

granting conscientious objector status only to those opposed to all wars did not violate the Establishment Clause even if that requirement disparately impacted certain religions).

${ }^{66}$ See Welsh v. United States, 398 U.S. 333, 356 (1970) (Harlan, J., concurring) (expressing the view that conscientious objector status cannot be granted to those with religious beliefs in pacificism without also granting the status to those with secular, moral beliefs in pacificism).

${ }^{67}$ See City of Richmond v. J.A. Croson Co., 488 U.S. 469, 509-11 (1989).

${ }^{68}$ See id.; see also Regents of the Univ. of Cal. v. Bakke, 438 U.S. 265, 307-09 (1978) (Powell, J.) (requiring judicial, legislative, or administrative findings of specific instances of discrimination before the government gives preferential treatment on compensatory grounds to individuals from a group whose members have been victims of discrimination).

${ }^{69}$ If this reconciliation is viewed as free exercise priority, I will accept it as such, on the sole ground that free exercise rights are held on an intensely personal and individualized basis, while nonestablishment rights are shared in common with all. 
of free exercise interests. By the same token, Establishment Clause "values" do not trump free exercise rights. This analysis of clause conflict, of course, makes it essential to be precise about the content and force of both religion clauses, and therefore precludes the kind of tilting associated with both separationism and accommodationism.

\section{B. Beyond Coercion}

The anti-accommodation argument rests as well on an understanding of equal religious liberty that transcends the notion of freedom from coercion. In both government and the academy, the proponents of accommodation recently have been advancing the idea that coercion is an essential element of an Establishment Clause violation. ${ }^{70}$ In the amicus brief for the United States in Lee $v$. Weisman, ${ }^{71}$ the public school commencement prayer case on this Term's Supreme Court docket, the government has boldly asserted this proposition, arguing that only those practices that coerce religious belief or observance should be held to violate the Establishment Clause. ${ }^{72}$ In particular, the government's brief argues that the plaintiff in Lee v. Weisman was not coerced because she was not "required" to participate in or "witness" the ceremony. ${ }^{73}$

The government's position is deeply flawed. First, it would essentially render the Establishment Clause superfluous. Government compulsion of individuals to attend and to participate in a religious ceremony offends core principles of political freedom and free exercise; individual choices concerning whether and how to engage in expression of religious significance may not be dictated by the state. ${ }^{74}$ An interpretation of nonestablishment that renders

${ }^{70}$ See County of Allegheny v. ACLU, 492 U.S. 573, 659-62 (1989) (Kennedy, J., concurring in part and dissenting in part); Michael W. McConnell, Coercion: The Lost Element of Establishment, 27 WM. \& MARY L. REV. 933 (1986).

71908 F.2d 1090 (1st Cir. 1990), cert. granted, 111 S. Ct. 1305 (1991) (No. 901014).

72 See Brief for the United States as Amicus Curiae Supporting Petitioners at 2028, Lee v. Weisman, 908 F.2d 1090 (1st Cir. 1990), cert. granted, 111 S. Ct. 1305 (1991) (No. 90-1014) [hereinafter Brief for the United States]. Indeed, the brief presents the case's sole question as "Whether government accommodation of religion in civic life violates the Establishment Clause, absent some form of government coercion." Id. at I.

${ }^{73} I d$. at $24,25$.

${ }^{74}$ See, e.g., Wooley v. Maynard, 430 U.S. 705, 717 (1977) (holding that New Hampshire's interest in requiring all state license plates to bear the motto "Live Free or Die" did not outweigh an individual's First Amendment right to refrain from 
it redundant cannot capture its meaning, ${ }^{75}$ original or otherwise, and should be avoided on general principles of constitutional construction.

Second, the definition of coercion is a matter of serious debate and difficulty. ${ }^{76}$ Once one gets beyond the obvious case of dire threats-your prayers or your life-there remain knotty problems of whether coercion attends conditioning government benefits upon participation or passive acquiescence in religious ceremony. The only way that Deborah Weisman could receive her junior high school diploma in front of her parents and the rest of the school community was to attend a ceremony that included prayers to which she and her family objected. Were she and they put to a coercive choice? ${ }^{77}$ If the community of which the Weismans are a part is likely to ostracize those who object to or absent themselves from a religious ceremony, is the government agency that sponsors that ceremony responsible for the social coercion that accompanies it?

expression); West Virginia State Bd. of Educ. v. Barnette, 319 U.S. 624, 642 (1943) (holding that a local rule compelling public school students to salute the flag violated the First Amendment). One of the disturbing features of Justice Scalia's opinion for the Court in Smith was its favorable citation of Minersville Sch. Dist. v. Gobitis, 310 U.S. 586 (1940), the decision that Barmette overruled. See Employment Div., Dep't of Human Resources v. Smith, 110 S. Ct. 1595, 1600 (1990).

75 See School Dist. v. Schempp, 374 U.S. 203, 223 (1963) (arguing that the right of individuals to avoid religious coercion is protected by the Free Exercise Clause; official support of government for religious tenets violates the Establishment Clause whether or not coercion is present).

${ }^{76}$ There is an elaborate literature on the legal and philosophical problem of defining coercion. See Richard A. Epstein, Unconstitutional Conditions, State Power, and the Limits of Consent, 102 HARV. L. REV. 4, 11-14 (1988) (highlighting and discussing the gap between common law notions of coercion and theories of unconstitutionally coercive conditions on government benefits); Seth F. Kreimer, Allocational Sanctions: The Problem of Negative Rights in a Positive State, 132 U. PA. L. REV. 1293, 1352 (1984) (arguing that the government's use of allocational sanctions is subject to constitutional constraint and that allocational sanctions should be analyzed by determining whether they are threats or offers); Lupu, Where Rights Begin, supra note 7, at 961-63 nn.106-13 and sources cited therein; Kathleen M. Sullivan, Unconstitutional Conditions, 102 HARV. L. REV. 1413, 1428 (1989) (criticizing traditional analyses of unconstitutional conditions for focusing wrongly on whether conditions coerce individuals and suggesting that courts should instead apply close scrutiny to these situations).

77 Rust v. Sullivan, 111 S. Ct. 1759, 1778 (1991), suggests that the Solicitor General and the Court's majority have a view of coercion that is narrow indeed. Rust is distinguishable, however, because the injury inflicted by the government upon pregnant women consisted of silence on questions regarding abortion, a subject about which a pregnant woman would know to inquire elsewhere. In Lee, by contrast, the public graduation ceremony was the only opportunity for community recognition of the achievement. 
Third, under any definition of what government practices constitute coercion, there remains a crucial question concerning the kind of coerced acts by individuals that are relevant to the inquiry. The government's brief in Lee focuses on coerced attendance at religious ceremonies, but what of coercive taxation to support the activities of churches? The Madisonian conception of church-state relations included such taxation as a vice to be condemned, ${ }^{78}$ but the proponents of accommodation have been content to limit their concern for coercion to ceremonial participation and taxation designed to finance explicitly spiritual activities of churches.

However coercion may be defined, the Establishment Clause is impoverished and distorted if it is limited to government action that coerces conduct. Suppose Congress charters a Church of the United States with explicit provisions that no person shall be compelled to attend and that no funds shall ever be drawn from the U.S. Treasury to support the Church in any way. The Church thereafter is built and operates exclusively through private financial support. Although no person is coerced in this scenario, can there be any doubt that the Act's provisions 1) granting the federal charter and 2) conferring the title of Church of the United States violate the Establishment Clause? No coercion is necessary to support a finding of violation when the statute straightforwardly delivers to this Church the prestige of association with the national government. ${ }^{79}$

Moreover, a theory premised on coercion ignores the comparative right to participate in, or not be excluded from, the benefits generated by the political community. ${ }^{80}$ It is difficult to argue in

${ }^{78}$ See MADISON, supra note 38.

${ }^{79}$ In his Allegheny opinion, Justice Kennedy suggested that government practices that "threatened" to establish a church might violate the Establishment Clause, even if such practices were not coercive. See County of Allegheny v. ACLU, 492 U.S. 573, 660-62 (1989) (Kennedy, J., concurring in part and dissenting in part). The brief for the United States in Lee echoes this suggestion. See Brief for the United States, supra note 72, at 6-7 (arguing that "civic acknowledgements of religion in public life do not offend the Establishment Clause, as long as they neither threaten the establishment of an official religion nor coerce participation in religious activities"). Neither Justice Kennedy nor the Administration offers any examples of a noncoercive practice that threatens to establish a state-sponsored religion, and it is possible that the hypothetical discussed in the text would qualify as such a threat. Why annual government sponsorship of a Christmas creche does not constitute such a threat is difficult for me to comprehend.

${ }^{80}$ See generally Kenneth W. Simons, Equality as a Comparative Right, 65 B.U. L. REv. 387, 416-52 (1985) (distinguishing between comparative and noncomparative constitutional rights). 
contemporary America that discrimination in the distribution of government benefits is not of constitutional significance. A program of government benefits for white persons only, or for Republicans only, would surely violate the Constitution, though the former cannot be viewed as coercive at all and the latter is coercive only in the weak sense of altering associational incentives. Religionbased distributions are similarly flawed. A federal program of discretionary grants to artists and writers may not be limited to Christians, even though the program may produce no coercion at all.

Such a result is reinforced by, but does not depend upon, the Equal Protection Clause. ${ }^{81}$ Sound constitutional intuition suggests that such a discrimination in the distribution of benefits would have been as invalid in $\mathbf{1 8 5 0}$ as today. One strand in the reasoning supporting such a result involves the 1787 Constitution's only religion clause, which provides that "no religious Test shall ever be required as a Qualification to any Office or public Trust under the United States." 82 The principle underlying this clause-that religious affiliation cannot be the basis for defining the relationship between a citizen and her government-strongly suggests that religious tests for any government benefit are unacceptable.

Even without regard to the "religious Test" Clause, however, the threat to Establishment Clause values arising from official discrimination is plain. If such discrimination were allowed, the government could create significant incentives to join a sect, and thereby manipulate religious allegiances in ways highly analogous to the psychic pressure generated by an established church. To use Dean Jesse Choper's language, such government activity may "compromise or influence religious choice." 83 Yet coercion, in the narrow

${ }^{81}$ For further analysis of this problem in explicit equal protection terms, see Brownstein, supra note 33, at 102-12; Lupu, Where Rights Begin, supra note 7, at $982-$ 87. See also David E. Steinberg, Note, Church Control of a Municipality: Establishing a First Amendment Institutional Suit, 38 STAN. L. REV. 1363, 1382-87 (1986) (noting that the religion clauses, like the Equal Protection Clause, protect group rights).

82 U.S. CoNST. art. VI, cl. 3; see also Torcaso v. Watkins, 367 U.S. 488, 496 (1961) (invalidating a state constitutional provision requiring state officials to declare their belief in God).

${ }^{83}$ Choper, supra note 63, at 700; see also William Van Alstyne, Trends in the Supreme Court: Mr. Jefferson's Crumbling Wall-A Comment on Lynch v. Donnelly, 1984 DUKE L.J. 770, 787 (asserting that American government is "Christian-pretending," and that "[1]ate arrivals to America" will "be made to feel ungrateful should they complain"). 
sense of threatened deprivation or punishment, is nowhere to be seen in such a scenario.

\section{The Case Agarnst Accommodation}

The case against accommodation, as I have defined it, rests on a variety of considerations. Some are overtiy derived from constitutional principles, primarily the Establishment Glause and its promise of equal religious liberty. A distinctly secondary set of considerations, removed from the Constitution, rests on social and political views concerning the special significance of religious association. Together, these two parts of the argument make up the substantive case against accommodation.

An additional set of premises in the case against accommodation are constitutionally rooted in a different sense; they draw on concerns associated with the decisional qualities of adjudication and the institutional qualities of the judiciary. These premises make up what I describe below as the institutional case against accommodation.

\section{A. The Substantive Case Against Accommodation}

The case against accommodation rests primarily on the constitutional promise of equal religious liberty. Equal religious liberty is simply one of a series of parallel constitutional commitments-equal respect for ideas, for consciences, for privacy, for racial, ethnic, or religious identity, and for voluntary associational choices. The strong prohibition in the law of free speech against government discrimination on the basis of speech content, for example, derives substantially from this sort of principle. ${ }^{84}$

Moreover, accommodationists like Professor McConnell cannot blithely ignore the need for some strong version of an equality principle in this field. Judges, such as Chief Justice Rehnquist, and commentators who support the broadest scope for the political accommodation of religion, and consequently, the narrowest version of nonestablishment, nevertheless concede that sectarian discrimination is unacceptable. ${ }^{85}$ Unfortunately, these judges and commen-

${ }^{84}$ See generally Kenneth L. Karst, Equality as a Central Principle in the First Amendment, 43 U. CHI. L. REV. 20, 20-21 (1975) (discussing "the principle of equal liberty of expression"). See also Susan H. Williams, Content Discrimination and the First Amendment, 139 U. PA. L. REV. 615, 666-76 (1991) (noting that general theories of equality apply to speech).

${ }^{85}$ See Wallace v.Jaffree, 472 U.S. 38, 106, 113 (1985) (Rehnquist, C.J., dissenting) 
tators never say why this is so, and much in the law of the religion clauses turns on the explanation. Regulation of religion is not like trade regulation; the state cannot proceed "one step at a time," singling out its favorite sects for benefits and its least favorite religious groups for detriments, and defending the discriminations on flimsy grounds of rationality. Some version of constitutional equality with real constraining force over political decisions is implicit in the prohibition on sectarian discrimination.

As constitutional lawyers and others have long recognized, however, equality is hardly a self-defining concept. For many years, constitutional battles have raged between two basic approaches to problems of constitutional equality. One approach asserts the normative proposition that government should not distribute benefits and burdens on the basis of traits over which the individual has little or no control-for instance, racial or gender identity. This approach, which of late has tended to appeal to political conservatives, has been assigned a variety of labels-formal equality, equality of opportunity, abstract equality, and individualistic equality. ${ }^{86}$ Although I do not like the pejorative associations evoked by the label "formal," I will use it in the context of equal religious liberty because others have used it.

The leading rival to the formal view begins with the proposition that we are all, to some extent, defined by the character of groups with which we are associated. Therefore, the state should affirmatively recognize the different histories and agendas of such groups, strive to preserve what is culturally distinctive about each, protect group members against subjugation and unreasonable discrimination, and fashion group-based remedies for group-based wrongs. Such an approach has attracted a set of labels opposing those

(stating that "preference among religious sects" is forbidden, but that the government may use "nondiscriminatory sectarian means" to pursue legitimate ends); Arlin M. Adams \& Charles J. Emmerich, A Heritage of Religious Liberty, 137 U. PA. L. REv. 1559, 1635 \& n.319 (1989) (noting that all religions stand as legal equals and that one cannot be favored over another).

${ }^{86}$ Recently, the voices most associated with this view are Justice Scalia, given his opinion in Gity of Richmond v. J.A. Croson Co., 488 U.S. 469, 527 (1989) (Scalia, J., concurring), and William Bradford Reynolds, who represented President Reagan's Department of Justice on these matters. See William B. Reynolds, Individualism vs. Group Rights: The Legacy of Brown, 93 YALE L.J. 995, 996 (1984). Political conservatives do not monopolize this view. See William Van Alstyne, Rites of Passage: Race, the Supreme Court, and the Constitution, 46 U. CHI. L. REv. 775, 775-79 (1979) (suggesting that the bad effects of allowing race into decisionmaking will more than offset any beneficial effects that affirmative action plans produce). 
enumerated above-substantive equality, equality of outcome or result, historical equality, and group equality. This version of equality theory tends to be associated, at least in the field of gender and race relations, with those commonly described as politically and constitutionally progressive. ${ }^{87}$ Although I dislike ceding the rhetorical advantage to rivals, here, too, there is precedent in the religion clause commentary for describing this approach as substantive. 88

In what follows, I develop and analyze both of these approaches in the context of equal religious liberty. The formal approach would forbid legislative accommodations of religion, except, perhaps, in cases in which legislatures simply anticipate what courts enforcing the Free Exercise Clause would in any event require. The substantive approach, by contrast, would require a great many legislative accommodations. The strongest case against accommodation combines the case against the substantive conception of equal religious liberty with the case for the formal conception.

\section{The Perils of Substance}

Substantive equality theory would be far more receptive to religion than would formal theory. Substantive theory requires affirmative sensitivity to religion rather than the benign neglect produced by formal theory. Substantive conceptions of religious equality require the state to guarantee that religious interests are not inadvertently overlooked in the political process. This, of course, means that actors in that process must be continuously

${ }^{87}$ See, e.g., Regents of the Univ. of Cal. v. Bakke, 438 U.S. 265, 379 (1978) (Brennan, J., concurring in part and dissenting in part) (providing a "progressive" viewpoint with respect to remedying past racial prejudice in university admissions); $i d$. at 400-02 (Marshall, J., concurring in part and dissenting in part) (allowing race to be considered in university affirmative action plans); $i d$. at 403-04 (Blackmun, J., concurring in part and dissenting in part) (arguing that group racial discrimination in medical school admissions must be remedied); see also Owen M. Fiss, Groups and the Equal Protection Clause, 5 PHIL. \& PUB. AFF. 107, 108 (1976) (stating that the progressive "group-disadvantaging principle" takes better account of the idea of equality); Charles R. Lawrence III, The Id, the Ego, and Equal Protection: Reckoning with Unconscious Racism, 39 STAN. L. REV. 317 (1987) (arguing in favor of a progressive view of racism in light of Washington v. Davis); Kathleen M. Sullivan, Comment, Sins of Discrimination: Last Term's Affirmative Action Cases, 100 HARV. L. REV. 78, 96-98 (1986) (explaining progressive, forward-looking justifications for affirmative action).

${ }^{88}$ For a comparable distinction between the formal and the substantive, see Douglas Laycock, Formal, Substantive, and Disaggregated Neutrality Toward Religion, 39 DEPAUL L. REV. 993, 999-1006 (1990). 
religion-conscious. Given the unlikelihood and presumptive impropriety of legislative focus on particular individuals in the formation of policy, this religion-consciousness will necessarily translate into sect-consciousness.

In this sect-conscious frame of mind, an accommodating legislature would presumably impose upon itself a set of substantive equality norms. First, inadvertent discrimination against religion generally or against particular sects should be avoided in the formation of policy. Second, religious practices should presumptively be afforded the same treatment as their secular analogues. A third, more specialized version of substantive equality might focus on the receptivity to claims concerning God or religion made in public fora, because the proponents of substantive equality for religion frequently contend that a secularized public forum reflects hostility, not neutrality, toward religion, and is therefore unacceptable. ${ }^{89}$

The first two concerns of substantive theory-rejection of secular monopoly or superiority and avoidance of sectarian discrimination, inadvertent or otherwise-will produce dramatic consequences. In some instances, particularly where the state's substantive interests are trivial, the results may seem generally desirable. What reasonable objections are there to making sure that dress codes do not inadvertently punish those who cover their heads or faces for religious reasons, ${ }^{90}$ or to taking steps to preserve quaintly unusual religious traditions like those of the Amish? ${ }^{91}$

Other contexts, however, will produce more troubling questions. Consider the case of parental responsibility for the physical wellbeing of minor children. A formal egalitarian would view this as a simple matter; all parents must make reasonable judgments concerning whether and when to seek conventional medical attention for an ailing child. Religious affiliation, or lack of it,

${ }^{89}$ See, e.g., RICHARD J. NeUHAUS, THE NAKED PUBLIC SQUARE 82 (1984) (asserting that since "government cannot help but make moral judgments of an ultimate nature," wholly secularized policy is really "secular humanism" or "ersatz religion").

${ }^{90}$ See Goldman v. Weinberger, 475 U.S. 503, 509-10 (1986) (upholding an Air Force dress code regulation that prevented an Orthodox Jew from wearing a yarmulke).

${ }^{91}$ See State v. Hershberger, 462 N.W.2d 393, 397-99 (Minn. 1990) (holding, in a case remanded by the U.S. Supreme Court for reconsideration in light of Smith, that the state constitution protects an Amish buggy-driver from a law requiring that slowmoving vehicles display a special emblem). 
would not operate to erase the potential culpability of those who breach custodial duties of this sort. ${ }^{92}$

A requirement of substantive equality would, by contrast, demand a very different approach. According to the substantive view, the privileging of science over faith constitutes unacceptable discrimination against religion. In order, therefore, to achieve substantive equality for religion, faith has to be put on a presumptively equal footing with the methods and insight of science. One committed to substantive equality for religion would ask whether, for some families, prayer and/or other spiritual healing techniques function equivalently to conventional medicine in the family life of others. If those who use doctors rather than prayer in the effort to heal their ailing children are presumptively not neglectful, or culpable if the children are not cured, should not those who use prayer instead of conventional medicine be equally immune to charges of neglect or assertions of culpability? ${ }^{93}$

The sort of problem presented by state policies concerning the physical care of children is replicated in the context of public school curricula. The conceptual connection between matters of race and religion is strong, if one recalls the debate about Euro-centered versus Afro-centered curricula. A set of arguments quite similar to

92 This has been the stable position of the courts in cases in which parental failure to seek medical care for an ailing child has appeared to be causally linked to the child's death. In such cases, free exercise claims have not prevailed. See, e.g., Walker v. Superior Court, 763 P.2d 852, 869-71 (Cal.) (holding that involuntary manslaughter and felony child-endangerment prosecutions of a Christian Science parent did not violate her free exercise rights), cert. denied, 491 U.S. 905 (1989).

${ }^{93}$ For a discussion from the perspective of Christian Science, see Thomas C. Johnsen, Christian Scientists and the Medical Profession: A Historical Perspective, in

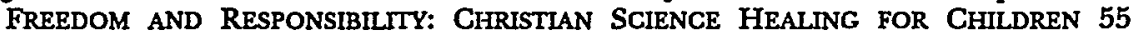
(Manager of Christian Science Committees on Publication ed., 1989) (tracing the development and legal acknowledgement of Christian Science spiritual healing in the early 1900s); David N. Williams, Christian Science and the Care of Children: The Constitutional Issues, in CHRISTIAN SCIENCE: A SOURCEBOOK OF CONTEMPORARY MATERIALS 181, 181-86 (Christian Science Publishing Society ed., 1990) (arguing that Christian Science healing is effective and consistent with secular standards of parental responsibility for children). For a similar perspective on questions of religious versus secular educational choices, see McConnell, supra note 61, at 1004 (analyzing religious and secular schools as "substitutes" in the economic sense). See also George W. Dent, Jr., Religious Children, Secular Schools, 61 S. CAL. L. REV. 863, 941 (1988) (noting that public education must not impede religion). The substantive view suggests as well that government programs that subsidize medical treatment, such as Medicare and Medicaid, must include faith-healers among the group of reimbursable providers. But cf. Rust v. Sullivan, 111 S. Ct. 1'759, 1771-76 (1991) (holding that regulations prohibiting the use of Title $\mathrm{X}$ funds for abortion counseling do not violate First Amendment free speech rights). 
those that support the case for Afro-centrist teaching underlies an accommodationist position as well; the teaching of secular versions of human origins and values creates substantive inequality between those families who instruct their children in such secular accounts and those who rely exclusively on theological explanations for our existence and for the presence of good and evil. A true multiculturalism must be responsive to religious as well as racial, ethnic, and other forms of diversity.

Accommodation of this concern, however, creates an unusually devilish set of problems. ${ }^{94}$ To what extent and with what tools are accommodationists prepared to remedy this sort of inequality? Is the answer separate classes for deeply religious children, or mandatory instruction for all children in religious as well as secular accounts of morality, creation, or social arrangements? If mandatory instruction is the answer, which religious account(s) will be offered?

In substantive equality theory, as in formal equality theory, sectarian discrimination is presumptively unacceptable. Any accommodation for faith-healing, for example, thus cannot be limited to respectable, educated, middle- and upper-middle class

94 See Edwards v. Aguillard, 482 U.S. 578, 596-97 (1987) (holding that Louisiana creationism and evolution instruction laws, mandating balanced treatment, are unconstitutional); Epperson v. Arkansas, 393 U.S. 97, 109 (1968) (finding that Arkansas anti-evolution teaching statute is unconstitutional); Mozert v. Hawkins County Bd. of Educ., 827 F.2d 1058, 1070 (6th Gir. 1987) (refusing to exempt public school students from using a school reader offensive to their religious beliefs), cert. denied, 484 U.S. 1066 (1988). The literature on these cases is extensive. See, e.g., Dent, supra note 93 (discussing the problems with and possible remedies for accommodating the rights of religious children in public schools); Stanley Ingber, Religion or Ideology: A Needed Clarification of the Religion Clauses, 41 STAN. L. REv. 233, 288-332 (1989) (distinguishing between sacred qualities of religion and human inspiration of ideologies, and applying the distinction to problems arising from the place of religion in the public school curriculum); Edward J. Larson, A Spectator's Guide to Aguillard v. Edwards: Part II Textbooks, Judges, and Science, 17 CUMB. L. REv. 116, 117 (1986) (referring to Aguillard as a new avenue for creationist arguments about instruction in public schools); Lupu, Where Rights Begin, supra note 7, at 942-44, 949-52 (discussing the Mozert decision and its implications in regard to the burdening of religious liberty); Mary H. Mitchell, Secularism in Public Education: The Constitutional Issues, 67 B.U. L. REV. 603, 664-746 (1987) (exploring the legal issues associated with promoting secularism in public schools); Nadine Strossen, "Secular Humanism" and "Scientific Creationism": Proposed Standards for Reviewing Curricular Decisions Affecting Students' Religious Freedom, 47 OHIO ST. L.J. 333, 336-54 (1986) (discussing legal challenges to the teaching of "secular humanism and scientific creationism" in public schools); Wendell R. Bird, Note, Freedom of Religion and Science Instruction in Public Schools, 87 YALE L.J. 515 (1978) (discussing various problems and possible solutions in regard to the teaching of evolution to religious children attending public schools). 
sects like the Christian Scientists, but must be extended to their grubbier or less well-known counterparts. ${ }^{95}$ Moreover, as a matter of political dynamics, accommodations will typically breed pressure for more accommodations. Public display of Christmas symbols will inevitably lead to demands for public display of symbols of Chanukah, Easter, and religious holidays heretofore less well-known in the West. Who will decide which symbols are displayed? For how long? How large, prominent, noisy, or otherwise intrusive may they be? In which public places? ${ }^{96}$

Relax. We know that the slide to full accommodation of these religious claims-all of which, when viewed from the perspective of adherents, are perfectly reasonable and highly compelling-is highly unlikely. The reason why that is so tells us much about the problems of substantive equality theory and the vices of accommodation. Those in the position to accommodate will have grave difficulty maintaining objectivity about where lines are to be drawn. Customary practices are likely to be accommodated; unusual ones are less likely to be so treated. Among the unusual practices, it is improbable that the more threatening ones will receive a warm reception from the state's decisionmakers. At most, the state will define its accommodation policy so as to limit its exposure to unknown or undesirable sects. ${ }^{97}$ A regime of accommodation, designed at least in part to produce substantive equality between nonreligious and religious interests, is highly likely to privilege mainstream, well-known religions, or locally dominant ones, and thereby to aggravate conditions of religious inequality.

The Constitution's architects were aware of dangers of this character. As Madison argued in Federalist No. 10, the spirit of faction is likely to be particularly strong in small communities. ${ }^{98}$

${ }^{95}$ See, e.g., Peyote Way Church of God, Inc. v. Thornburgh, 922 F.2d 1210, $1213-$ 20 (5th Cir. 1991) (upholding refusal to exempt Peyote Way from prohibition on peyote use, despite federal statutory and regulatory exemptions for Native American Church). For further examples of the legislative tendency to be overtly or covertly sect-specific, see Lupu, supra note 4.

${ }^{96}$ For a comparable problem in the political speech context, see Lehman v. City of Shaker Heights, 418 U.S. 298, 303-04 (1974) (upholding refusal of municipal transit system to accept political advertising on the ground that it would create difficult problems of rationing). For the suggestion that these problems be solved by a rule that allocates to all religious holidays whatever time and space are publicly allocated to the holiday most heavily observed in public institutions, see Lupu, supra note 4.

${ }^{97}$ For more detailed analysis of this point, see Lupu, supra note 4.

98 The FEDERALIST No. 10, at 22 (James Madison) (Roy P. Fairfield ed., 1981). 
Moreover, the danger presented by religious faction may be stronger than other types of division. Because religion tends to speak to questions of ultimate truth and not merely to matters of interest, the intensity of reaction and intolerance produced by accommodation fights may be among the most extreme our politics can produce. Indeed, as attractive as the image of multicultural diversity and harmony may be, the experience of other nations with the relationship of religious sectarianism to politics is hardly encouraging. ${ }^{99}$

Thus, it seems truly unimaginable that a regime of politically selected and approved accommodations will produce results consistent with any overarching, theoretically sound conception of substantive religious equality. A regime of purported substantive religious equality will probably turn out to be quite the opposite. For instance, the distinctions between accommodations made and those not made will frequently rest on religious prejudice, ignorance, or other unacceptable grounds. In a pro-accommodation climate, such distinctions are likely to stand undisturbed.

\section{The Substance of Formalism}

Theories of formal equality depend on a judgment that certain traits constitute impermissible bases for defining groups for purposes of government policy. Qualities like race, gender, and ethnicity are the most commonplace examples of such traits in our constitutional law of equality. Under formal theory, once such categories are identified, it matters not whether the object of government policy is the majority or the minority, the powerful or the dispossessed. Policies that favor African-Americans or women, for example, are presumptively as troublesome, under formal theory, as are policies favoring Caucasians or men. ${ }^{100}$ The bright lines produced by formal theory are typically defended on grounds of fairness, because the theory offers protection against the imposition of burdens on the basis of traits for which persons cannot be held responsible, and on prophylactic grounds of

99 See, e.g., S.R. BALESHI, CoNGress, MUSLIM LEAGUe AND Partition OF INDIA (1990); JOHN FUlTON, THE TRAGEDY OF BELIEF: DIVISION, POLITICS, AND RELIGION IN IRELAND (1991); WINFRED E. GARRISON, INTOLERANCE (1934).

${ }^{100}$ See City of Richmond v. J.A. Croson Co., 488 U.S. 469, 528 (1989) (Scalia, J., concurring); see also Metro Broadcasting v. Federal Communications Comm'n, $110 \mathrm{~S}$. Ct. 2997, 3044-45 (1990) (Kennedy, J., dissenting) (arguing that racial classifications embodied in law are presumptively impermissible). 
preventing tyranny, because the theory limits the danger of invidious classifications masquerading as benign.

In the context of the religion clauses, formal equality produced a famous proposal from Professor Kurland: Religion cannot be the explicit basis of any classification, either beneficial or detrimental, by any branch of government. ${ }^{101}$ The Kurland principle would have forbidden permissive accommodations and judicially-mandated free exercise exemptions. Moreover, the principle would have permitted a great deal of aid to religious institutions, so long as their religious character was not the basis for the aid. Primarily because of this pro-aid, anti-separationist consequence, Kurland's view was unacceptable to many scholars and judges of his generation. ${ }^{102}$

As Professor Tushnet has recently argued, however, the principle of formal equality has powerful and attractive virtues. ${ }^{103}$ Most prominent among these is what he calls its "administrability"; the principle is hard and fast, and departures from it are typically quite easy to identify. The possibility of manipulation and invidious discrimination against unpopular religions will be much less in a formal as compared to a substantive regime, though general sensitivity to claims of religion will also diminish. Were the Kurland principle to be modified to allow for judicially identified, religionspecific exemptions required by the Free Exercise Clause, ${ }^{104}$ the principle of formal religious equality would probably be the

${ }^{101}$ See Philip B. Kurland, Of Church and State and the Supreme Court, 29 U. CHI. L. REv. 1, 6 (1961).

${ }^{102}$ Soon after its publication, the Kurland principle was rejected in the context of free exercise exemptions as well. See Sherbert v. Verner, 374 U.S. 398, 410 (1963) (holding that South Carolina's unemployment laws may not burden a Sabbatarian's free exercise rights by forcing "a worker to abandon his religious convictions respecting the day of rest"). Employment Division, Department of Human Resources v. Smith, 110 S. Ct. 1595 (1990), has since resurrected Kurland's thesis, but only with respect to judicial enforcement of the Free Exercise Clause. See Smith, 110 S. Ct. at 1600 ( $[$ [T] he right of free exercise does not relieve an individual of the obligation to comply with a valid and neutral law of general applicability on the ground that the law proscribes . . . conduct that his religion prescribes . ..." (quoting United States v. Lee, 455 U.S. 252, 263 n.3 (1982) (Stevens, J., concurring in the judgment))).

${ }^{103}$ See Mark Tushnet, "Of Church and State and the Supreme Court": Kurland Revisited, 1989 SuP. CT. REv. 373, 374-75.

104 The suggested modification is mine, not Professor Tushnet's. His piece follows closely on the heels of another in which he seemed more sympathetic to the accommodationist view. See Mark Tushnet, The Emerging Principle of Accommodation of Religion (Dubitante), 76 GEO. L.J. 1691, 1691 (1988) (pointing out that the accommodation principle is "normatively attractive" but difficult to "work out as a coherent principle of constitutional adjudication"). 
soundest single solution to the general problems of the religion clauses.

The principle of formal religious equality would, of course, automatically forbid discretionary accommodations. Accommodations are, by definition, religion-specific, and therefore represent prima facie violations of the principle. The easiest cases under the principle are 1) explicit preferences for one or more sects over others, and 2) preferences for members of religious sects over religious individuals. The first of these cases is illustrated by statutes that protect Christian Scientists, but not others who reject conventional Western medicine on religious grounds, from application of child abuse laws, ${ }^{105}$ and by laws that exempt Native American Church members, but not members of other religions in which peyote use is sacramental, from criminal prohibitions on drug use. ${ }^{106}$ The second sort of breach of formal equality-preferring sects to individuals-is less common. The conscientious objector provision in early versions of the Selective Service laws did this, ${ }^{107}$ and the sect preferences described above do so indirectly, by excluding individuals as well as the nonpreferred sects from their protective umbrella.

The principle of formal religious equality would also end the unhappy judicial struggle over the content and context of the display of religious holiday symbols at public expense. A body of case law that approves of public support of Nativity Scenes in parks

105 See John T. Gathings, Jr., Note, When Rights Clash: The Conflict Between a Parent's Right to Free Exercise of Religion Versus His Child's Right to Life, 19 CUMB. L. REv. 585, 586-87 nn.7-8 (1989) (listing state statutory religious exemptions from the duty to provide medical care for their children when such care conflicts with parents' faith healing beliefs, and pointing out that some states require that the parents' beliefs be part of a "recognized" religion); see also Ivy B. Dodes, Note, "Suffer the Little Children ....": Toward A Judicial Recognition of a Duty of Reasonable Care Owed Children by Religious Faith Healers, 16 HOFSTRA L. REv. 165, 177-78 \& nn.69-71 (1987) (discussing Christian Scientist exemptions and benefits); JoAnna A. Gekas, Note, California's Prayer Healing Dilemma, 14 HASTINGS CoNST. L.Q. 395, 396 (1987) (noting that California protects "recognized' religions over unrecognized religions"); Daniel J. Kearney, Note, Parental Failure to Provide Child with Medical Assistance Based on Religious Beliefs Causing Child's Death-Involuntary Manslaughter in Pennsylvania, 90 DICR. L. REV. 861, 861-62 (1986) (noting that the Faith Tabernacle Church is not exempt from child abuse laws in Pennsylvania).

${ }^{106}$ See Peyote Way Church of God, Inc. v. Thornburgh, 922 F.2d 1210, 1213-20 (5th Cir. 1991) (holding that federal and Texas laws exempting the Native American Church but not exempting Peyote Way from peyote possession prohibitions are constitutional).

${ }_{107}$ See United States v. Seeger, 380 U.S. 163, 171 (1965) (citing early Selective Service laws). 
next to Santa and his reindeer, ${ }^{108}$ and Chanukah menorahs next to Christmas trees, ${ }^{109}$ but disapproves of Nativity Scenes in courthouse hallways, ${ }^{110}$ does not inspire confidence. ${ }^{111}$ Justice O'Connor's test of whether such displays constitute "endorsements"112 represents a step in the right direction, because it reflects concern for equality of religious liberty. The test has been soundly criticized for its manipulability, unpredictability, and pseudo-objectivity, ${ }^{113}$ however, and we would best move beyond "endorsement" to a standard that quite simply bars state-supported display of all messages and symbols with commonly perceived religious content. If none of these symbols may be publicly

${ }^{108}$ See Lynch v. Donnelly, 465 U.S. 668, 671 (1984).

109 See County of Allegheny v. ACLU, 492 U.S. 573, 620 (1989).

110 See id.

111 Moreover, it does not discourage continued litigation over such questions. See, e.g., Doe v. Small, 934 F.2d 743, 746 (7th Cir. 1991) (holding that the Establishment Clause prohibits the city from encouraging, authorizing, and endorsing Christmas season display of series of 16 paintings depicting scenes from the life of Jesus); Cammack v. Waihee, 932 F.2d 765, 782 (9th Cir. 1991) (holding that the Establishment Clause does not prohibit the state from making Good Friday an official holiday); Doe v. Village of Crestwood, 917 F.2d 1476, 1479 (7th Cir. 1991) (holding that city sponsorship of Italian Mass as part of holiday festival violates Establishment Clause), petition for cert. filed, 59 U.S.L.W. 3726 (U.S. Apr. 8, 1991) (90-1573); Harris v. City of Zion, 927 F.2d 1401, 1402 (7th Cir. 1991) (holding that the Establishment Clause forbids use of Latin Cross on municipal seal), petition for cert. filed, 60 U.S.L.W. 3154 (U.S. Aug. 19, 1991) (No. 91-299); North Carolina Civ. Lib. Union v. Constangy, 751 F. Supp. 552, 555 (W.D.N.C. 1990) (holding that the Establishment Clause prohibits state judge's practice of opening court each day with a prayer), affd, 1991 WL 212995 (4th Cir. 1991).

112 See County of Allegheny, 492 U.S. at 623-27 (O'Connor, J., concurring); Lynch v. Donnelly, 465 U.S. 668, 687-94 (1984) (O'Connor, J., concurring); see also County of Allegheny, 492 U.S. at 595-97 (Blackmun, J., for the Court in part and dissenting in part) (applauding O'Connor's notion that "any endorsement of religion [is] 'invalid'").

113 See, e.g., William P. Marshall, "We Know It When We See It": The Supreme Court and Establishment, 59 S. CAL. L. REV. 495, 536 (1986) (arguing that O'Connor's test is deficient because it requires a subjective determination of what constitutes an "endorsement"); Steven D. Smith, Symbols, Perceptions, and Doctrinal Illusions: Establishment Neutrality and the "No Endorsement" Test, 86 MICH. L. REv. 266, 267 (1987) (arguing that O'Connor's "no endorsement" test would introduce "further ambiguities and analytical deficiencies" into the Court's Establishment Clause analysis). 
subsidized, none can be invidiously favored or disfavored. ${ }^{114}$ In any event, formal religious equality presses toward such a result.

More complex questions are presented by preferences for religious over nonreligious association generally. As noted in Part I, above, the Supreme Court has wavered in its treatment of such policies. In Corporation of the Presiding Bishop of the Church of Jesus Christ of Latter Day Saints v. Amos, ${ }^{115}$ the Supreme Court upheld an accommodation in the employment discrimination context; in Texas Monthly, Inc. v. Bullock, ${ }^{116}$ the Court invalidated a religionspecific tax exemption as a forbidden establishment.

The larger question raised by any policy that treats religious institutions differently from all others is the extent to which the Constitution permits religious association to be privileged over nonreligious association. ${ }^{117}$ Nonreligious association includes but goes beyond those associations whose raison d'etre is opposition to religion. Nonreligious association includes all other categories of intermediate associations-for example, labor unions, political parties, neighborhood associations, and cause-oriented groups. All of these associations may serve some of the social and political functions served by churches; they may be mediating institutions, devoted to some version of the virtuous or pleasant life, buffering the individual and enhancing her power in dealing with the large, impersonal institutions of the state. Moreover, all such associations presumably would prefer to be as free as churches are in selecting

114 One might create an exception to such an admittedly prophylactic rule in cases in which the context overwhelmed any possibility that the display would be perceived as an endorsement. Thus, paintings of religious subjects might be displayed in stateoperated art galleries, when it was plain that artistic merit rather than religious content was the selection criterion. Cf. Small, 934 F.2d at 746 (holding that the Establishment Clause prohibits the city from encouraging, authorizing, and endorsing Christmas season display of series of 16 paintings depicting scenes from the life of Jesus).

${ }^{115} 483$ U.S. 327 (1987).

116489 U.S. 1 (1989); see also Estate of Thornton v. Caldor, 472 U.S. 703, 710-11 (1985) (holding that state statute requiring employers to accommodate those employees who were Sabbath observers was unconstitutional); Larkin v. Grendel's Den, Inc., 459 U.S. 116, 126-27 (1982) (invalidating state statute authorizing churches and schools, but not other institutions, to block the issuance of liquor licenses to nearby premises).

${ }^{117} \mathrm{I}$, unlike many others who write in this field, make sharp distinctions among religious individuals, religious association, and "corporate" religious bodies. Part of my concern resides in the danger of faction, which religious individuals acting alone do not present, and part resides in my conviction that the Free Exercise Clause should be read as a guarantor of individual, and not corporate, liberty. See Lupu, Religious Institutions, supra note 7, at 422-23. 
employees committed to their cause, in being free from taxation or in any other way being exempt from governmentally imposed burdens.

The theory of equal religious liberty, formal or otherwise, cannot satisfactorily answer questions concerning the relative status of religious and nonreligious association, but overarching themes in constitutional law can resolve this dilemma. For purposes of stateindividual mediation generally, or for purposes of inculcating virtue in particular, religious association cannot be preferred to nonreligious counterparts. ${ }^{118}$ Nonreligious associations may perform many of the psychological, social, political, and economic functions commonly associated with religion; that is, they may help individuals make the world smaller and more coherent, teach and help to preserve the continuity of values, proselytize, develop and maintain ritual, promote good or evil, provide support in times of trouble or sorrow, and facilitate commercial transactions among members who know and trust one another. Indeed, the only distinctive function of religion is spiritual and theological, and these concerns must remain outside the legitimate boundaries of the state's power to promote or retard. 119 Thus, whether or not it violates any version of equal religious liberty, legislative preference for religious associations over others violates equal associational liberty.

The Supreme Court's doctrines about aid to religious organizations have been sensitive to this concern, even though the proponents of accommodation have not. The Court tends to uphold such programs only if they exhibit a breadth of coverage sufficient to include nonreligious organizations. It was on this basis that twenty years ago the Court upheld state property tax exemptions for religious institutions, ${ }^{120}$ and this consideration has been among

118 We have begun to realize that the reverse is also true. See Board of Educ. v. Mergens, 110 S. Ct. 2356, 2372-73 (1990) (upholding requirement of Equal Access Act that religious student groups be afforded treatment equal to nonreligious groups in schools that maintain an open forum for extracurricular activities).

119 This point is further developed in Stephen G. Gey, Why is Religion Special?: Reconsidering the Accommodation of Religion Under the Religion Clauses of the First Amendment, 52 U. PITT. L. REV. 75, 166-85 (1990) (arguing that the qualities that make religion distinctive are those that government may not promote).

${ }^{120}$ See Walz v. Tax Comm'n, 397 U.S. 664, 680 (1970). 
the bases for evaluation of state programs for aid to private schools. ${ }^{121}$

In addition, the Court's narrow interpretation of the Title VII requirement that employers (public and private) reasonably accommodate their employees' religious practices ${ }^{122}$ is explicable in light of the principle of equal associational liberty. The requirement has always been at war with the basic theory of Title VII; all of its other prohibited discriminations reflect a focus on status rather than conduct choices. In TWA $v$. Hardison, ${ }^{123}$ the Supreme Court reduced the dissonance in the statute by glossing the "reasonable accommodation" provision to limit an employer's duty to that of providing "de minimis" accommodations. ${ }^{124}$ These developments can, of course, be analyzed in terms of the economic burden that would be imposed upon others if the requirement were to be construed more vigorously; the greater the workplace accommodation of religious practice, the greater is the forced subsidy of observant employees by employers and fellow employees. If coercive taxation to support the religious practices of others is a constitutional vice, so is coercive regulation of one's economic affairs to the same end. ${ }^{125}$

Another powerful objection to the accommodation requirement, however, relates to its discrimination among voluntary associations. Title VII privileges employees' conduct choices driven by religious concerns, but omits protection of, inter alia, parenting practices, political association, and other practices motivated by deep attachments to communities other than the workplace. Moreover, except for the exemption for religious institutions upheld in Amos, the statute does not require similar accommodation for the religious, or other associational, concerns of employers about the composition of the workforce. ${ }^{126}$ The "de minimis" interpreta-

121 See, e.g., Mueller v. Allen, 463 U.S. 388, 390, 396 (1983) (holding that a state statute providing deductions for educational expenses did not violate the Establishment Clause when applied to those who attended religious schools).

122 See 42 U.S.C. $\$ \S 2000 \mathrm{e}(\mathrm{j}), 2000 \mathrm{e}-2(\mathrm{a})(1)-(2)(1988)$.

123432 U.S. 63 (1977).

124 See id. at 84-85. In Ansonia Board of Education v. Philbrook, 479 U.S. 60, 69 (1986), the Court limited the duty still further by holding that the employer need not consider the employee's accommodation proposal if the employer's proposal is itself a reasonable one.

125 See supra text accompanying notes 70-83.

126 See State v. Sports and Health Club, 370 N.W.2d 844, 853 (Minn. 1985) (en banc), appeal dismissed, 478 U.S. 1015 (1986) (rejecting claim by employer that it was motivated by Christian principles and, accordingly, should be free to limit hiring to 
tion in Hardison thus limits the damage to equal associational liberty that otherwise might be worked by employment discrimination law.

Not all of the consequences of formal equality theory, or of associational equality, are to the detriment of religion. Most significantly, under such a theory, programs of government aid to institutions that carry out public purposes (such as education or helping the poor) would have to include religious institutions. This would produce sweeping, religion-favoring alterations in the law of nonestablishment, under which direct financial aid to religious entities remains limited. ${ }^{127}$

The law here is changing faster than many have noticed, however. The Supreme Court's 1988 decision in Bowen $v$. Kendrick ${ }^{128}$ suggests a strong likelihood that the law of direct aid, designed for secular purposes, that includes religious beneficiaries is moving strongly in the direction of formal equality and away from a strictly separationist, no-aid view. Although I question the outcome of Bowen v. Kendrick, because of the theological tilt in its aid criteria, ${ }^{129}$ its deeper underpinnings reflect a doctrine of formal equality. So long as government decisionmakers are not motivated by a covert desire to aid religion qua religion, or to aid a particular religion, religious institutions should be eligible for the same kind and degree of assistance as other institutions serving the same purpose in a nonreligious setting. ${ }^{130}$ This is not accommo-

\section{Christians).}

${ }^{127}$ See, e.g., Grand Rapids School Dist. v. Ball, 473 U.S. 373, 397-98 (1985) (holding that programs funded by the public for nonpublic school students in religious schools violate the Establishment Clause); Aguilar v. Felton, 473 U.S. 402, 414-15 (1985) (holding that it is unconstitutional for the city of New York to use federal funds to pay public school employees teaching remedial, non-religious subjects in parochial schools).

128487 U.S. 589 (1988).

${ }^{129}$ The Adolescent Family Life Act authorized grants to organizations for purposes of responding to problems of teen-age sexuality and pregnancy, but the grants could not be used for abortion counselling or services. See 42 U.S.C. $\$ 300 z-7$ to -10 (1988). Rust v. Sullivan, 111 S. Ct. 1759, 1764 (1991), reinforces the idea that government may tilt aid against information that might facilitate the choice to terminate a pregnancy.

${ }^{130}$ As I suggest above, and suggest further in The Trouble with Accommodation, the Supreme Court has been heading toward but has not yet arrived at this position. See Lupu, supra note 4. The stumbling block appears to be the problem of ensuring that public monies serve secular purposes, such as educating children, and not religious purposes of inculcation. If an answer requires an absolute guarantee of no such crossover, the problem is insoluble. If, however, allocation of costs between secular and religious components of an enterprise is thought constitutionally feasible, economic methods for so doing are available. See Jesse H. Choper, The Establishment 
dation, as I have defined it; however, it is a distinct and dramatic alteration in the doctrine of separation, which I believe to be as flawed as accommodation when viewed from the perspective of equal liberty. ${ }^{131}$

It bears noting that the general constitutional law of equality, at least in the field of race, has moved increasingly in the direction of formality. ${ }^{132}$ The proponents of accommodation thus bear the burden of explaining why (contrary to the developing case law) the substantive view is to be generally preferred as a norm of constitutional equality, or, alternatively, why religious equality should be subject to a set of constitutional norms different from those applicable in the field of race or gender.

The accommodationists have, it seems to me, two responses to this. First, as Professor Laycock has argued, rights under the Free Exercise Clause are substantive and noncomparative and are thereby of a different character than rights under the Equal Protection Clause. ${ }^{133}$ This is correct, as far as it goes, but it does not go nearly far enough to support the position of Professor McConnell, who has urged accommodation well beyond what the Constitution guarantees as a matter of right. The case for discretionary accom-

Clause and Aid to Parochial Schools, 56 CAL. L. REV. 260, 340 (1968) (proposing a rule that governmental aid to parochial schools be deemed constitutional to the extent the aid not exceed the value of the schools' secular services); McConnell \& Posner, supra note 6 , at 20-30 (discussing different economic methods of determining when government action impinges on religious choice).

131 I take it to be among the central points in Professor McConnell's recent essay comparing funding of abortions and religious schools, that the law should not privilege secular education over religious education. See McConnell, supra note 31, at 1046 (arguing that the government should fund religious schools if it funds secular schools absent a "plausible, non-hostile reason for selective funding").

132 Croson suggests this is so in the law of voluntary affirmative action, where the Carolene Products perspective has been yielding to more formal approaches. Washington v. Davis, 426 U.S. 229 (1976), rejected the substantive egalitarian view that the racially disparate impact of a facially race-neutral policy was of independent constitutional significance. Thus, the Constitution has been increasingly read not to require, and indeed to limit, government reliance on substantive theories of racial equality. There is, of course, substantial literature to the contrary. See, e.g., T. Alexander Aleinikoff, A Case for Race-Consciousness, 91 ColuM. L. REv. 1060 (1991) (arguing that color-consciousness is essential to racial justice); David Chang, Discriminatory Impact, Affirmative Action, and Innocent Victims, 91 CoLUM. L. REV. 790, 793 (1991) (arguing that affirmative action programs should only be invalidated if they were adopted out of racial prejudice); Michael J. Perry, The Disproportionate Impact Theory of Racial Discrimination, 125 U. PA. L. REV. 540, 586-89 (1977) (criticizing the Washington $v$. Davis court for its inappropriate analysis of the disproportionate racial impact issue); sources cited supra note 87.

133 See Laycock, Remnants, supra note 13, at 13-21. 
modations cannot depend upon the substantive content of the Free Exercise Clause, and it is thus left in need of a different argument to distinguish the case of religious equality from race or gender equality.

Second, accommodationists might respond, regimes of formal equality in the fields of race and gender formally privilege no one, ${ }^{134}$ but the regime of formal religious equality will privilege the secular. ${ }^{135}$ In a universe of substantive religious equality, by contrast, the realm of the secular is not similarly privileged.

This assertion of secular advantage in the formal, anti-accommodationist view is not merely true; it is constitutionally appropriate and balanced, and politically desirable. Constitutional propriety for secular privilege is supported by the Constitution's Preamble-it is Liberty's Blessings, not God's, that we are trying to secure "to ourselves and our Posterity." ${ }^{\text {186 }}$ The constitutional balance inheres in the relationship between the religion clauses; the Free Exercise Clause allows the privileging of religious individuals over nonreligious ones, and the Establishment Clause reverses the privilege for all matters not protected by the requirement of free exercise. This arrangement protects the essentials of religious liberty and helps to insulate politics against the strife of religious faction.

134 The substantive equality argument is that regimes of formal equality will tend in fact to privilege groups with relatively more political power.

${ }^{135}$ For an unusual variant on possible meanings of the secular, see Steven D. Smith, Separation and the "Secular": Reconstructing the Disestablishment Decision, 67 TEx. L. REV. 955, 985-88 (1989).

${ }^{136}$ U.S. CoNST. pmbl. See Milton Handler, Brian Leiter \& Carole E. Handler, A Reconsideration of the Relevance and Materiality of the Preamble in Constitutional Interpretation, 12 CARDOZo L. REV. 117, 119 (1990) (suggesting that the Preamble provide guidance in the resolution of important constitutional issues). The notion of secular privilege also helps explain cases such as Epperson v. Arkansas, 393 U.S. 97, 109 (1968), wherein the Court held that the Constitution forbids enactment of a law removing the teaching of Darwinian evolution from public schools, because the law's passage was motivated by a protectionist concern for religious Creationism. For elaboration of the general argument about the requirement of secular privilege, see Gey, supra note 119, at 116-85. The only "pro-religious" item in the 1787 Constitution is at its very conclusion, in which the Constitution is declared to have been "Done in Convention . . . the Seventeenth Day of September in the Year of Our Lord one thousand seven hundred and Eighty-Seven and of the Independence of the United States of America the Twelfth." U.S. CoNST. art. VII. 


\section{Political and Social Concerns About Accommodation}

Accommodations are troublesome for reasons that transcend the likely violence they will inflict upon equality of religious liberty. If political entities may make religion-specific policies even when not so required by the Constitution, a number of unappealing consequences may follow.

First, religion-specific policies promote the concept of religion as an interest, looking after the tangible concerns of its members, rather than acting as a force for moral good. This perception has hurt racial minorities and has the potential to backfire similarly on religious institutions; religious spoils systems are no more attractive than their racial counterparts. When religious entities pursue moral ends, such as aid for the poor or world peace, they seek objectives that have secular translation and secular benefits. ${ }^{137}$ Although such policies may "accommodate" religious precepts, they can be politically defended in religion-neutral terms. ${ }^{138}$ By contrast, the efforts by religious institutions to secure political recognition of holidays, customs, or deviant social practices may appear narrowly self-interested and may thereby undercut religion's moral force.

Second, some acts of accommodation may undercut the project of constitutional democracy, which depends upon a citizenry capable of exercising independent and critical judgment concerning policies and leaders. Voluntary associations may provide a setting in which these skills can be enhanced in small, face-to-face interactions. Religious institutions, however, frequently claim divine inspiration of their principles and leaders as a basis of power and legitimacy. Such claims discourage skepticism and make intense demands for obedience by adherents. The Constitution requires toleration of such institutions, but it would be constitutional folly to

137 See generally KENT GREENWALT, RELIGIOUS CONVICTIONS AND POLITICAL CHOICE (1988) (discussing the problem of religiously motivated arguments in public policy arenas); MICHAEL J. PERRY, LOVE AND POWER: THE ROLE OF RELIGION AND MORALITY IN AMERICAN POLITICS (forthcoming 1991).

${ }^{138}$ When such policies are not easily translated into secular terms, they are most politically suspect. The anti-abortion movement most enhances its political appeal when it plays to arguments with obvious secular translation, such as the concern of the elderly and the disabled that their lives may become viewed by others as "low quality" and therefore dispensable. For a chilling demonstration that such political movements can be as non-rational as purely religious ones, see Peter Singer, On Being Silenced in Germany, N.Y. REv. Books, Aug. 15, 1991, at 36, 36-42 (describing hostility and intolerance towards ideas of medical ethics that permit withdrawal of life supports from patients in some circumstances). 
read the Establishment Clause to permit support and encouragement for intermediate institutions that undermine rather than mutually reinforce habits of mind necessary for democratic decisionmaking. ${ }^{139}$

Third, Professor McConnell's political case for accommodation rests in part on the notion that, for those with deep religious beliefs, theological claims may be "prior to and of greater dignity than the claims of the state." 140 Indeed, Professor McConnell asserts that the Constitution itself embodies the view that religious claims are superior to claims of the state. ${ }^{141}$ For many individuals in the society, this ranking may well be descriptively accurate, and the cases in which that is so are likely to be the strongest candidates for free exercise protection.

This sort of challenge to the legitimacy and authority of the state, however, is the most fundamental of all that might be advanced. Concessions to such challenges should be limited to situations in which they are persuasively and demonstrably appropriate, and they should not be made subject to majoritarian political processes. Political refusal to make voluntary accommodations may be profoundly disrespectful to deeply held theological views that support the accommodation request. In addition, political willingness to make such accommodations may, in a different way, undermine religion by breeding cynicism and disrespect for the character of religious claims and claimants.

Moreover, such concessions to claims of theological superiority over secular norms should not be extended in a generalized and overbroad way to those who do not in fact hold such views. Voluntary accommodations are errors in statecraft, because they will run 1) to those who do not hold religious claims to be morally superior to the claims of the state, as well as to those who do, and 2) to those whose assertions of religious claims may be fraudulent. A state unwisely undermines its authority to govern when it makes reflexive, overbroad, and imprecise jurisdictional concessions to rivals for popular support and authority. One expects the state's law to reflect the political community's version of the First Com-

139 See Gey, supra note 119 , at $172-80$.

140 McConnell, Accommodation, supra note 6, at 15; see also McConnell, Revisionism, supra note 11, at 1152 (asserting that the Free Exercise Clause, as understood by James Madison, reflects the theological position that God is sovereign).

141 “[T]he Free Exercise Clause is not an expression of the will of the sovereign but a declaration that the right to practice religion is jurisdictionally beyond the scope of civil authority." McConnell, Revisionism, supra note 11, at 1151. 
mandment-the state first, other institutional loyalties thereafter. ${ }^{142}$

\section{B. The Institutional Case Against Accommodation}

For those, like myself, attracted to the virtues of formal equality, there remains the broader question of whether free exercise exemptions from general laws are ever acceptable. Professor Kurland, applying his principle across the constitutional board and without regard to which governmental institution is acting, believes they are not. His theory would forbid a statutory exemption for the use of wine in religious ritual from a legislative prohibition on alcohol use, and would similarly block courts from importing such an exemption by way of the Free Exercise Clause. In his view, if the policy arguments for prohibition were sufficiently strong, they would simply trump religious concerns; conversely, if the religious convictions on the matter were sufficiently widespread or persuasive, the general prohibition scheme would not be enacted. No "accommodations" are possible. ${ }^{143}$

This view seems rigid, creating zero-sum games when other possibilities seem present. This view would also result in some substantive violence to religious choices. Moreover, Kurland's view treats all concerns on policy matters as having equal weight; therefore, it neglects the possibility that the Free Exercise Clause might require special recognition of the unusual character and high intensity of religious commitments. ${ }^{144}$

142 Different Bible translations offer differing translations of the First Commandment. Compare "Then God spoke all these words: I am the LORD your God, who brought you out of the land of Egypt, out of the house of slavery; you shall have no other gods before me." Exodus 20:1-3 (The New Oxford Annotated Bible) (footnote omitted) with "God spoke, and these were his words: I am the LORD your God who brought you out of Egypt, out of the land of slavery. You shall have no other God to set against me." Exodus 20:1-3 (The New English Bible) (footnote omitted).

143 See supra note 101 and accompanying text.

144 See generally John H. Garvey, Free Exercise and the Values of Religious Liberty, 18 CONN. L. REV. 779 (1986) (discussing the factors that make religious commitments unusual). 


\section{The Preference for Courts}

The path of reconciliation of the regime of formal religious equality with the commands of the Free Exercise Clause is institutional, not substantive. ${ }^{145}$ The $S$ mith Court was exquisitely correct in focusing upon the institutional question-which branch of government, if any, may specially recognize religion specific claimsbut precisely wrong in its response.

My view matches Professor Kurland's in its bluntness, though not in its conclusion. Courts, adjudicating cases in which free exercise claims are raised, may respond affirmatively to those that are meritorious. Nonadjudicative decisionmakers should not enact religion-specific solutions-that is, they should not accommodate as I have defined the term-even if they have strong grounds on which to believe that courts will require them to do so. Moreover, executive branch officials, such as prosecutors, should be at least as constrained as legislators. ${ }^{146}$

To some, this iron rule of institutional allocation will no doubt seem counterintuitive or worse. It appears to invite legislative and executive branch activity that unconstitutionally fails to exempt religiously motivated conduct of a sort that courts will ultimately protect. Such an institutional rule favors those religious groups with the will and resources to litigate over those who prefer to engage in direct political action. The rule will presumably not maximize religious liberty in the way Professors Laycock and

145 The argument in text reflects a larger view that considerations of institutional trustworthiness are of central significance in constitutional law. See generally JoHN HART ELY, DEMOCRACY \& DISTRUST: A THEORY OF JUDICIAL REVIEW (1980) (arguing that judicial review should focus on remedying malfunctions in the other branches of government); Neil K. Komesar, Taking Institutions Seriously: Introduction to a Strategy for Constitutional Analysis, 51 U. CHI. L. REV. 366 (1984) (proposing a comparative institutional approach to constitutional law).

146 When administrative agencies act quasi-judicially, they should act like courts and be receptive to claims of free exercise exemption from general laws. This is consistent with the line of cases upholding free exercise claims in the unemployment compensation context. See Frazee v. Illinois Dep't of Employment Sec., 489 U.S. 829 (1989); Hobbie v. Unemployment Appeals Comm'n, 480 U.S. 136 (1987); Thomas v. Review Bd., 450 U.S. 707 (1981); Sherbert v. Verner, 374 U.S. 398 (1963). But see Employment Div., Dep't of Human Resources v. Smith, 110 S. Ct. 1595 (1990) (holding that the Free Exercise Clause does not require the state to exempt unemployment compensation claimants from general definition of misconduct). When agencies act in their rule-making capacities, however, the dangers of political accommodation remain. Indeed, to the extent that political factions are more likely to dominate agencies than legislatures, the dangers here are acute and worthy of special attention. 
McConnell would do by providing free exercise interests two or more chances to prevail. ${ }^{147}$ Moreover, the rule may appear terribly inefficient; why should religious groups have to litigate to enforce rights which legislatures or executives might voluntarily provide?

Nevertheless, this kind of sharp institutional distinction is prophylactically essential to the joint project of respecting religion's constitutional place while simultaneously avoiding invidious religious discrimination. For reasons derived from the institutional analysis that follows, I would introduce to constitutional law the concept of questions that are "justiciable only"-that is, questions that political branches should perceive as committed to adjudication alone as a decision procedure-and I would make special treatment for religion the first member of the set.

\section{a. The Obligation to Decide}

Courts typically have mandatory jurisdiction; ${ }^{148}$ they must decide the merits of cases properly before them. In contrast, other branches of government are not similarly obliged to respond to the merits of all requests that they exercise their power. This political discretion allows elected officials simply to ignore accommodation requests from religious groups lacking in numbers, resources, or other indicia of political influence. The power to ignore the claims of the less influential significantly increases the likelihood of invidious discrimination among religions. ${ }^{149}$

117 See Laycock, Remnants, supra note 13, at 15; McConnell, Revisionism, supra note 11 , at 1149-50. When one recalls the possibility of favorable executive or administrative action, as well as legislative or judicial, it becomes apparent that accommodationists would provide more than two chances in a number of contexts.

${ }^{148}$ This is not true of the Supreme Court. My argument, however, is that those advancing free exercise claims have a constitutional right to a meaningful opportunity to be heard. That sort of due process of the Free Exercise Clause does not require Supreme Court review any more than the procedural guarantees associated with any clause so require. See generally Henry P. Monaghan, First Amendment "Due Process, " 83 HARV. L. REV. 518 (1970) (arguing that sensitive procedural devices are necessary whenever First Amendment claims are involved). 55.

${ }^{149}$ See Laycock, supra note 88, at 1015-16; Laycock, Remnants, supra note 13, at 54- 


\section{b. The Significance of Written Decision}

Courts must not only decide the merits of cases properly before them; they are, in addition, obliged by a strong sense of institutional custom to describe the factual world put before them in litigation and to give reasons for their decisions. This obligation of description and rational explanation helps ensure intellectual honesty and consistency by making public the judge's account of 1 ) the religious character of the claim; 2 ) the content of legal norms relevant to the disposition of the claim; 3) the credibility and persuasiveness of the state's response to the claim; and 4) the application of the relevant norm and the appropriate conclusion. Indeed, free exercise claims typically involve traditions that are out of the mainstream; thus, they depend strongly upon thick description, first by the litigants to the judge and then by the judge to the outside world. ${ }^{150}$

In contrast, political branch response to accommodation requests are not encumbered by any comparable device to ensure intellectual honesty, thorough description, or accountability to any coherent formula for governmental response to such claims. The absence of such institutional decision procedures means that all accommodation decisions will be ad hoc, thus aggravating the risk of invidious discrimination.

\section{c. The Requirement of Principle}

Although free exercise adjudication obviously requires legal judgment, it does not necessarily, contrary to the assertion in Smith, involve the exercise of policy discretion or balancing of interests. Judicial decisions must rest on norms that transcend the immediate context in which they are applied. ${ }^{151}$ Because decisions by other branches are not similarly constrained, the risk is greater that their accommodations of religion will turn more on political favoritism and influence than on judgments of constitutional entitlement or acute religious need.

The contention that judicial decisions may rest on norms different in character from those employed elsewhere in governance is deeply controversial as a jurisprudential matter. That controversy has been particularly acute in constitutional law, ${ }^{152}$ though it is by note 4.

${ }^{150}$ For elaboration of this quality of free exercise adjudication, see Lupu, supra

${ }^{151}$ See Herbert Wechsler, Toward Neutral Principles of Constitutional Law, 73 HARV.

L. REV. 1, 19 (1959).

152 See, e.g., Mark V. Tushnet, Following the Rules Laid Down: A Critique of 
no means so limited. To make matters worse for my argument, judicial application of free exercise principles has often been condemned, by myself 'and' others, as reflecting unprincipled religious bias, quarter-hearted commitment, the desire to marginalize religion, and a tendency to be result-oriented. ${ }^{153}$

I do not intend to use this paper as a forum for the general defense of the possibility of principled decisionmaking under the Free Exercise Clause. Nevertheless, I believe that the argument against accommodation holds whether or not such decisionmaking is possible.

First, if we assume the worst-that judicial decisions are simply another form of political choice, as vulnerable as any other to the corrosion of bias, ${ }^{154}$ and, therefore, not entitled to any special constitutional status-then accommodations will never rest on grounds of general principle. If that is so, however, accommodations will always create invidious distinctions and should be minimized. One way of minimizing accommodations is to limit them institutionally to the judicial branch and substantively to those

Interpretivism and Neutral Principles, 96 HARV. L. REv. 781 (1983) (arguing that the construction of a satisfactory constitutional theory is either impossible or unnecessary).

${ }_{153}$ See Steven Pepper, Taking the Free Exercise Clause Seriously, 1986 B.Y.U. L. REv. 299; Lupu, Where Rights Begin, supra note 7, at 934 n.6, 945-46; Tushnet, supra note 103 , at 381-83.

154 Judges can engage in acts of invidious discrimination. The record in matters of religion, however, suggests that judges may have done somewhat better than they are usually given credit for. First, in the Supreme Court alone, the victors in free exercise cases have included Jehovah's Witnesses, Seventh-Day Adventists, the Amish, an individual who apparently deviated from his religion's conventional teachings, and another individual without any religious affiliation at all who claimed to celebrate a Sabbath. See Frazee v. Illinois Dep't of Employment Sec., 489 U.S. 829 (1989) (nonreligious Sabbath claimant); Thomas v. Review Bd., 450 U.S. 707 (1981) (conventional teachings deviant); Wisconsin v. Yoder, 406 U.S. 205 (1972) (Amish); Sherbert v. Verner, 374 U.S. 398 (1963) (Seventh-Day Adventists); West Virginia State Bd. of Educ. v. Barnette, 319 U.S. 624 (1943) (Jehovah's Witnesses); Cantwell v. Connecticut, 310 U.S. 296 (1940) (Jehovah's Witnesses). The losers in the Supreme Court have also included minority religions. See Jimmy Swaggart Ministries v. Board of Equalization, 493 U.S. 378 (1990) (Fundamentalist Christians); Hernandez v. Commissioner, 490 U.S. 680 (1989) (Scientologists); Lyng v. Northwest Indian Cemetery Protective Assoc., 485 U.S. 439 (1988) (Non-Christian Native American); Bowen v. Roy, 476 U.S. 693 (1986) (Non-Christian Native American); Goldman v. Weinberger, 475 U.S. 503 (1986) (Jews); Bob Jones Univ. v. United States, 461 U.S. 574 (1983) (Fundamentalist Christians); Braunfeld v. Brown, 366 U.S. 599 (1961) (Jews). Rather, reflecting the Constitution's secularist orientation and/or the bias common among many well-educated Americans against any form of intense religious commitment, the Court has been somewhat skeptical of all. 
situations in which judges can plausibly-though dishonestly and unpersuasively-defend them as matters of principle. ${ }^{155}$ This version of the world is unattractive, but it is no worse, and probably better, than the pseudo-pluralistic version in which politicians are trading special privileges for religion in exchange for political support.

Alternatively, if we assume judicial choices to respond favorably to religious claims of special treatment are in fact based on constitutionally sound and general principles, then my argument for institutional monopoly over this breed of decisions becomes far stronger. Exemptions granted by judges will rest exclusively on a foundation of general norms, applicable to free exercise claims from across the "spectral march"156 these cases exhibit. In contrast, voluntary accommodations will rest on an uneasy and unprincipled foundation of concern for religious liberty and the political strength of pro-accommodation forces. ${ }^{157}$ Without the force of general principle, there can be no guarantee that like claims to accommodation will be treated alike; without such like treatment, equal religious liberty will be perpetually undermined.

\section{d. The Limitation on the Scope of Judicial Decisions}

On whatever basis it rests and whatever its theoretical legitimacy, judicial decisionmaking in free exercise cases creates tangible and immediate benefits only for litigating parties. Although the parties may in other contexts include large classes, free exercise cases rarely if ever involve class claims. The reason is rooted in a

${ }^{155}$ Accommodations would be eliminated completely by adoption of the Kurland view, but that would do violence to all bona fide exemption claims. See supra note 101 and accompanying text.

${ }^{156}$ See Lupu, Where Rights Begin, supra note 7, at 947 ("Behind every free exercise claim is a spectral march; grant this one, a voice whispers to each judge, and you will be confronted with an endless chain of exemption demands from religious deviants of every stripe.").

157 Indeed, some of the Court's worst acts of prejudiced response to religion clause problems may have come in cases in which voluntary accommodations have been challenged as establishments. In Lynch v. Donnelly, 465 U.S. 668 (1984), for instance, the Court turned a blind eye to a context in which the state quite dramatically threw its weight behind a particular religious tradition. In a reaction of bias polar to that found in Lynch, the Court's decisions concerning aid to parochial schools show significant signs of anti-Catholicism. See Lemon v. Kurtzman, 403 U.S. 602,635 (1971) (assuming that "indoctrination" occurs in parochial elementary and secondary schools in Pennsylvania, in which the huge majority of parochial schools at the time were Roman Catholic). 
crucial element of free exercise doctrine: exemptions under the clause belong only to those individuals who sincerely believe that a particular religious obligation should override the state's competing demands and who are themselves burdened by those demands in a constitutionally cognizable manner. ${ }^{158}$ Each beneficiary of a court's decision, either as a party or as a subsequent claimant relying on principles of stare decisis, must be able to make this showing of sincerity. By contrast, legislative and executive accommodations may invite participation by the sincere and insincere alike. ${ }^{159}$ In such cases, religion absorbs the bad odor of those who act fraudulently in its name.

\section{e. The Role of Uniformity}

Accommodationists such as Professor McConnell argue that the concept rests on the federal constitutional value of religious liberty, ${ }^{160}$ and simultaneously seek to free individual states from the force of a number of existing federal constitutional constraints relating to religion. Although federalism arguments always have a respectable constitutional pedigree, they are usually at war with true protection of the liberties insulated from state power by the Bill of Rights.

The constitutional norms I defend here do not suffer similarly. Judicial decisions that rest on federal constitutional command purport to apply principles that are, in theory, of equal and uniform force throughout the nation. Although lower courts may diverge in results reached in free exercise cases, Supreme Court review will help unify the field. In contrast, accommodations by state legislatures will 1) create a nonuniform pattern of special treatment for religious concerns; 2) present an aggravated risk of special treatment for religions dominant in particular states; and 3) create the further risk of invidiously omitted accommodations for those

${ }^{158}$ See generally Lupu, Where Rights Begin, supra note 7 (discussing and analyzing the "burden" problem).

159 This was true, for example, of the accommodation invalidated in Estate of Thornton v. Caldor, Inc., 472 U.S. 703 (1985), in which the Court found an Establishment Clause violation in a Connecticut statute which required employers to permit employees to designate, and thereby avoid work on, a Sabbath day. The Court's rationale unpersuasively focused on the burden inflicted thereby on employers. In addition to the fact that the scheme favored Sabbatarian (i.e., Western) religions over others, the statute also protected the equivalent of "fraudulent" free exercise claims.

${ }^{160}$ See McConnell, Accommodation, supra note 6, at 1. 
religions which are in disfavor. ${ }^{161}$ And, if the broad view of accommodation prevails, there will be little or no review of the sort necessary to promote and maintain uniformity of federal constitutional principles.

\section{The Question of Institutional Cooperation}

An overarching institutional question arises from the sharp distinction I have drawn between judicial vindication of free exercise claims, which I have defended, and accommodations by other branches, which I have opposed. Assume, in the extreme case, that the Supreme Court recognizes the validity of a particular free exercise claim-for example, the freedom to discriminate on the basis of gender in the selection of clergy. ${ }^{162}$ May Congress, or a state legislature, codify that principle in its employment discrimination statutes? If so, is there any reason why legislatures cannot act first, anticipating free exercise exemptions that might be approved by courts? ${ }^{163}$

The latter question is easier than the former. Legislatures should not be free to so anticipate. Doing so would simply be a voluntary accommodation, couched in the language of constitutional duty. If legislatures take the lead in declaring such duties, courts may soon withdraw from the forefront of that enterprise. The

${ }^{161}$ State courts may extend state constitutional provisions beyond the federal Free Exercise Clause. Indeed, in the wake of Smith, some have begun to do so as a mechanism for insulating their pro-exemption results from federal review. See, e.g., State v. Hershberger, 462 N.W.2d 393, 396-97 (Minn. 1990) (holding that the state constitution exempts an Amish buggy-driver from general law requiring that slowmoving vehicles display special emblem); Society of Jesus v. Boston Landmarks Comm'n, 564 N.E.2d 571, 573 (Mass. 1990) (holding that the designation of a church interior as historical landmark, precluding alteration, is forbidden by the state constitution). Although state constitutional law, elaborated by state judges, may also be infected by bias, the institutional arguments advanced above hold with equal force in the state setting, at least in those states in which judges are appointed rather than elected.

${ }_{162}$ See McClure v. Salvation Army, 460 F.2d 553 (5th Cir. 1972) (construing Title VII of the 1964 Civil Rights Act to exclude religious bodies, hiring for positions of religious significance, from the statutory prohibition on gender discrimination), cert. denied, 409 U.S. 896 (1972). For critical commentary on McClure and its progeny, see Lupu, Religious Institutions, supra note 7, at 396-99.

${ }^{163}$ For the view, substantively but not institutionally akin to mine, that the limit of "accommodations" by legislatures is the free exercise boundary as crafted by courts, see Jonathan E. Nuechterlein, Note, The Free Exercise Boundaries of Permissible Accommodation Under the Establishment Clause, 99 YALE L.J. 1127, 1139 (1990). For an analysis that tilts in the institutional direction suggested here, see Developments in the Law, supra note 12, at 1731-40. 
temptation to duck the political responsibility for religion-specific decisions is always great, and the best institutional mechanism we have for avoiding invidious discriminations among religions is a vigilant judiciary, willing and able to take such responsibility. An overly aggressive legislature may too easily undermine that vigilance and induce a posture of deference in the judicial branch. That sort of deference would be the enemy of the constitutional values reflected in the religion clauses.

Whether legislatures should be able to follow judicial leads presents a harder question. Once courts have ordered a particular free exercise exemption, it seems on the surface both efficient and fair for legislatures to ratify such norms and to establish orderly procedures for their implementation.

Even in this context, however, danger exists. A free exercise holding by a court is highly particular, containing conclusions that certain parties, who may or may not be members of identifiable sects, are entitled to special treatment. In what terms can that be ratified as a matter of generalizable policy? Suppose, for example, that the Supreme Court had reached the opposite result in Smith. What policies would legislatures be required, and therefore permitted, to follow? That religious use of peyote was always privileged against unemployment benefit denials? Against criminal prosecution? That such use was privileged if engaged in by members of the Native American Church? By members of any church in which peyote use was a ritual? A central ritual?

Legislative reinforcement of free exercise principles will typically produce one of two kinds of adjudicative contexts. When legislatures exempt religious institutions from policies that convey benefits to private third parties, those parties may attack the religious institution's exemption as violating the Establishment Clause. If the exemption falls, and religious institutions are thereby swept into the policy's scope, the benefit to third parties will be restored by operation of law. ${ }^{164}$

In such cases, courts must ask the narrow and precise question of whether the exemption is, on the facts, required by the Free

${ }^{164}$ See, e.g., Estate of Thornton v. Caldor, Inc., 472 U.S. 703 (1985) (upholding an employer challenge to a state accommodation policy that swept beyond the more limited accommodations required by Title VII); $c f$. Presiding Bishop v. Amos, 483 U.S. 327 (1987) (refusing to deny the application of section 702 of Title VII, which exempts religious organizations from the statute's prohibition of religious discrimination, in the face of an employee Establishment Clause challenge). 
Exercise Clause; that is, the question should be identical to the one which the court would have had to resolve at the behest of the religious institution had no exemption been made. In order to preserve judicial supremacy over special treatment for accommodations, therefore, all such adjudication must be on an as-applied basis. Courts should simply not see themselves as empowered to proclaim that an entire category of exemptions, facts pertaining to which are not before the court, is required by the Free Exercise Clause and therefore the permissible subject of religion-specific legislation. ${ }^{165}$

The other category of litigation that will follow from legislative attempts to reflect free exercise principles will involve efforts to extend religion-specific benefits to nonreligious actors. The classic example of this pattern is Texas Monthly, in which a nonreligious periodical sought a refund of sales taxes paid pursuant to a state statute which exempted from the tax religious literature "published or distributed by a religious faith." 166 Such a case presents the substantive dilemma of whether the accommodation is permissible, and the remedial problem of whether the religious actor should henceforth bear the burden of the tax, or, alternatively, whether the prevailing nonreligious actors should now be exempted from the tax. The maintenance of incentives to litigate Establishment Clause questions suggests that extension of benefits outside the statutorily exempted class should be a federally mandated and presumptively applicable remedy in such cases, but the Supreme Court has not taken this view; rather, it has treated the question of remedy in such cases as one to be left to state decisionmakers. ${ }^{167}$

The substantive questions in this category of accommodation cases, however, will always present a contest of free exercise concerns which arguably support the exemption and competing

165 The breadth of voluntary accommodations, and the absence of case-by-case scrutiny of constitutional entitlement to their benefits, is sometimes defended as a good, because of the elimination of inquiry into the religious bona fides of particular claims. On the view offered here, however, such inquiry is always required, because the legitimacy of special treatment of religion depends on a finding of religious bona fides in the individual case. Accommodation is a free exercise remedy, and its validity depends on the existence of a free exercise right.

166 Texas Monthly, Inc. v. Bullock, 489 U.S. 1, 5-6 (1989).

167 This is consistent with its view in nonreligion cases presenting analogous problems of remediation. See, e.g., Orr v. Orr, 440 U.S. 268 (1979) (invalidating state rule limiting the benefit of alimony claims to women, but remanding to state court the question of whether the husband was obliged to continue making alimony payments on the basis of any gender-neutral state laws). 
concerns for equality-religious equality, expressive equality as in Texas Monthly, or associational equality-which arguably undermine it. Only if the Free Exercise Clause requires the exemption can the competing equality claims be defeated. This principle, while powerfully substantive, has strong process implications as well in this class of cases. In such cases, the exempted religious organizations become constitutionally indispensable third parties to the litigation; ${ }^{168}$ the state should not even be permitted, much less required, to speak for religious actors in defense of constitutional claims that depend upon unique qualities of religious belief, organization, or experience. When the state has taken the side of free exercise, a kind of inverse "due process" should apply. Here, as elsewhere in the law pertaining to special treatment for religion, sound constitutional adjudication depends on religious actors speaking for themselves. ${ }^{169}$

\section{Revisiting Employment Division, Department of Human Resources v. Smith}

In many areas of law, court-legislative partnerships are of course desirable and productive. This field, however, is not one of them. In the context of special treatment of religion, positive acts by the political branches will generally produce more detriments to the principle of equal religious liberty than benefits to the principle of religious liberty per se. Smith is thus profoundly wrong on both substantive and institutional grounds, and the voluntary accommodations it invites will in the long run do far more harm than good to the ends of the religion clauses. ${ }^{170}$

${ }^{168}$ Amicus participation by interested religious groups will usually provide a sufficient solution to the problem. In cases in which such groups do not file voluntarily, however, judges should make it a practice to invite them to do so. $C f$. Scott J. Ward, Note, Reconceptualizing Establishment Clause Cases as Free Exercise Class Actions, 98 YALE L.J. 1739, 1745-54 (1989) (arguing for a free exercise-class action approach to the Establishment Clause).

169 For elaboration of this principle in other settings, see Lupu, Religious Institutions, supra note 7, at $421-22$ (criticizing free exercise exemptions for institutions because individuals may hide insincerity behind institutional masks); Lupu, Home Education, supra note 7, at 979-90 (defending state policies designed to limit parental authority to assert religious reasons in support of home education for their children).

170 The recently reintroduced Religious Freedom Restoration Act, H.R. 2797, 102nd Cong., 1st Sess. (1991), designed to overrule Smith by Act of Congress, presents interesting problems in light of the argument I have advanced. To the extent it only requires courts to do what the Free Exercise Clause requires, it does not 
So long as Smith is the law, however, is my anti-accommodation stance a reasonable one? If accommodation is limited to the special treatment the Free Exercise Clause requires, and that Clause requires none, is no accommodation permissible? Two answers are possible, but only one seems appealing. One might say that the Free Exercise Clause still "requires" special treatment for religion in some instances, but that courts will not enforce the requirement. ${ }^{171}$ Under this theory, legislatures would remain free to accommodate to some undefined extent. Second, one might simply adhere to the logic of the no accommodation position and conclude that legislatures may be no more generous to religion than are courts. If courts cannot single out religious actors for special treatment by force of the constitution, then all the equality concerns that run against such special treatment by legislatures continue to apply unabated. On this view, contrary to Smith's dicta, the decision will result in no accommodation of religion by any branch of government. $^{172}$

I am attracted to this second position not only by the force of the argument I have advanced in this essay; I am drawn to it as well by Smith's fatal assault on the underpinnings of the pro-accommodation argument. Prior to Smith, accommodationists had vigorously

run afoul of the model I offer. If the results of the Supreme Court's decisions are the best evidence of what the Free Exercise Clause requires, however, the Act goes "too far," because it does much more than restore the prior law, and therefore privileges religion and religious association over other constitutionally protected commitments.

Moreover, the Act would probably be unconstitutional as applied to state policies; that is, by overturning Smith, it purports to substitute its own general rule of decision for the Court's on the scope of the Free Exercise Clause, and therefore exceeds the scope of congressional power to enforce the Fourteenth Amendment. See, e.g., Oregon v. Mitchell, 400 U.S. 112, 118, 124-31 (1970) (holding that the 1970 Amendment of the Voting Rights Act authorizing eighteen year olds to vote is unconstitutional insofar as it pertains to state and local elections). Some applications of the Act to state policies might be supportable under the commerce or spending power. With respect to federal legislation and policy, Congress may, by legislation, require obedience to an overarching general norm.

${ }^{171}$ See Lupu, supra note 4. See generally Sager, supra note 59, at 1220-28 (arguing that "underenforced" constitutional norms are valid to their constitutional limits).

172 Justice Stevens, who joined in Smith but has an activist view of nonestablishment, is the member of the Court most likely to support this. See Laycock, supra note 88 , at 1010 (asserting that Stevens is hostile to religion, insofar as he votes to maintain governmentally imposed burdens on religion but votes to block the distribution of government benefits to it); see also Laycock, Remnants, supra note 13, at 14 (" [Stevens] prefers even-handed [religious] repression to imperfect [religious] liberty."); id. at 35 (accusing Justice Stevens of singling out for disfavored treatment free exercise claims that prevail in state courts). 
advocated that special treatment of religious actors occur across the governmental board; that is, that the political branches voluntarily accommodate religion while the judicial branch adjudicate interstitially for the protection of those religious claims that failed in the political process. ${ }^{173}$ Put more simply, accommodationists believed that the system as a whole would protect religions generally, including unpopular minority religion. Now that Smith has dramatically undercut the possibility of judicially maintained backstopping of accommodation by enforcement of free exercise principles, the accommodationist stance is thus more than ever a source of support for mainstream religion. There should be little appeal to a constitutional theory of the religion clauses that, under current free exercise principles of institutional allocation, helps most those who need it least.

\section{CONCLUSION}

The zone of permissive accommodation is sometimes defined as the open space between the First Amendment's religion clauses; that is, the room for special treatment for religion by the political branches is whatever religion-specific treatment is neither required by the Free Exercise Clause nor forbidden by the Establishment Clause. The trend in the law of late, marked on the free exercise side by Smith, and on the Establishment Clause side by Bowen $v$. Kendrick, ${ }^{174}$ is to widen this zone considerably by reducing the demands of both clauses.

These trends should be resisted and reversed. If we are to have a regime of equal religious liberty, judges must in the name of the Constitution reassert control over distinctive treatment of religion. When the Constitution requires such treatment, courts should fearlessly order it; but whatever is not required is presumptively proscribed, and courts should with equal courage invalidate forbidden forays by the political branches into the field of religious

173 See McConnell, Revisionism, supra note 11 , at 1136.

174487 U.S. 589, 600-18, 621 (1988) (holding that the federal government may include religious organizations as grantees under the Adolescent Family Life Act, and restricting the scope of Establishment Clause limits to situations in which religious organizations have used government funds to proselytize). 
accommodation. Religion is, as others have argued, constitutionally unique, ${ }^{175}$ but what makes it so should be held to disable, not facilitate, political choices that focus on the subject.

${ }^{175}$ See generally Michael E. Smith, The Special Place of Religion in the Constitution, 1983 SUP. CT. REV. 83 (discussing and analyzing the Court's view that special treatment of religion is particularly likely to be judged unconstitutional). 